\title{
National Ignition Facility Project Input for Assessment of Environmental Impacts of NIF for the Sitewide Environmental Impact Statement
}

October 2003 


\section{DISCLAIMER}

This document was prepared as an account of work sponsored by an agency of the United States Government. Neither the United States Government nor the University of California nor any of their employees, makes any warranty, express or implied, or assumes any legal liability or responsibility for the accuracy, completeness, or usefulness of any information, apparatus, product, or process disclosed, or represents that its use would not infringe privately owned rights. Reference herein to any specific commercial products, process, or service by trade name, trademark, manufacturer, or otherwise, does not necessarily constitute or imply its endorsement, recommendation, or favoring by the United States Government or the University of California. The views and opinions of authors expressed herein do not necessarily state or reflect those of the United States Government or the University of Califormia, and shall not be used for advertising or product endorsement purposes.

This report has been reproduced directly from the best available copy. Available to DOE and DOE contractors from the Office of Scientific and Technical Information

P.O. Box 62, Oak Ridge, TN 37831

Prices available from (615) 576-8401, FTS 626-8401

Available to the public from the

National Technical Information Service

U.S. Department of Commerce

5285 Port Royal Rd.,

Springfield, VA 22161

This work was performed under the auspices of the U.S. Department of Energy, National Nuclear Security Administration by University of California Lawrence Livermore National Laboratory under Contract W-7405-Eng-48. 


\section{National Ignition Facility \\ Project Input for Assessment of \\ Environmental Impacts of NIF \\ for the Sitewide Environmental \\ Impact Statement}

Sandra Brereton

LAWRENCE LIVERMORE NATIONAL LABORATORY

University of California • Livermore, California 994550 



\section{NIF Project Input for Assessment of Environmental Impacts of NIF}

1. INTRODUCTION 1

2. NO ACTION ALTERNATIVE. 4

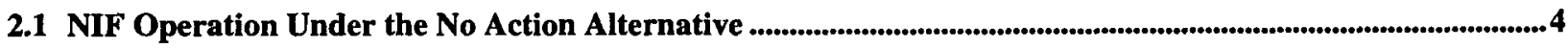

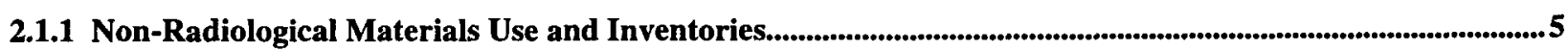

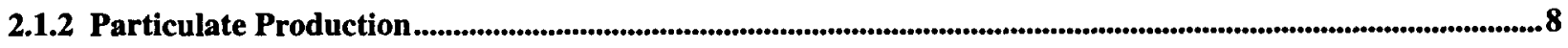

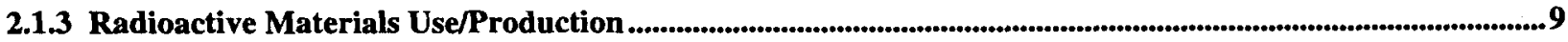

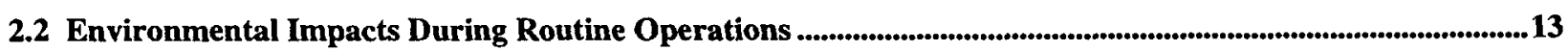

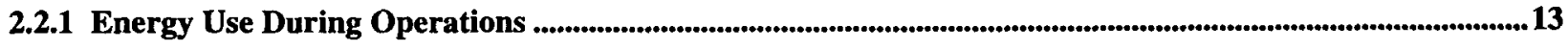

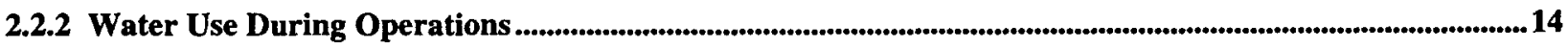

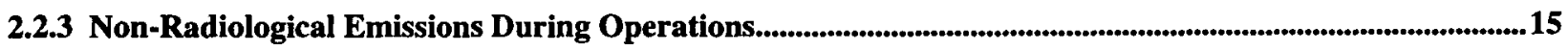

2.2.4 Radiological Emissions and Worker Exposures During Routine Operations ..............................................16

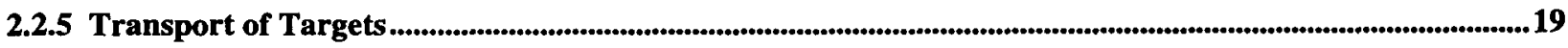

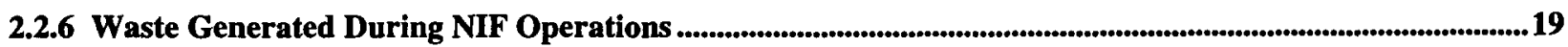

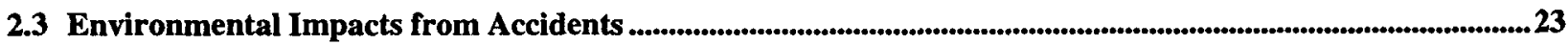

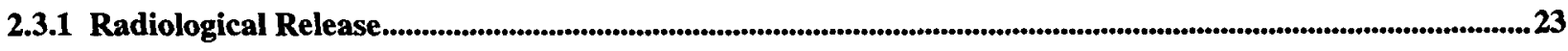

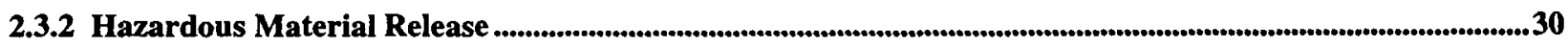

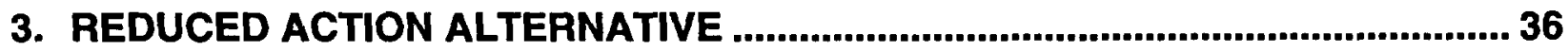

3.1 NIF Operation Under the Reduced Action Alternative ..................................................................................36

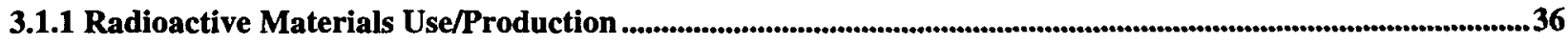

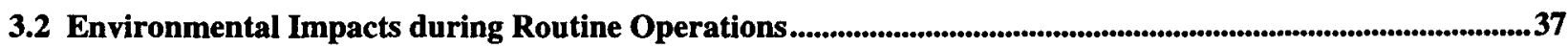

3.2.1 Radiological Emissions and Worker Exposures during Routine Operations ................................................37

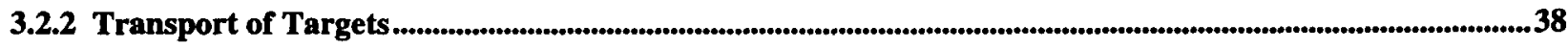

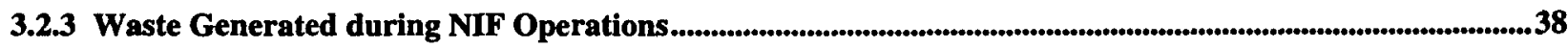


4. PROPOSED ACTION ............................................................................... 40

4.1 NIF Operation Under the Proposed Action Alternative .......................................................................................40

4.1.1 Particulate Production

4.1.2 Radioactive Materials Use/Production .......................................................................................................................43

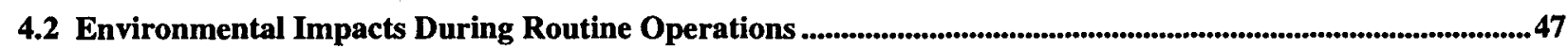

4.2.1 Radiological Emissions and Worker Exposures During Routine Operations ......................................................47

4.2.2 Transportation of Targets .............................................................................................................................................5

4.2.3 Waste Generated During NIF Operations ........................................................................................................................50

4.3 Environmental Impacts from Accidents.....................................................................................................................5



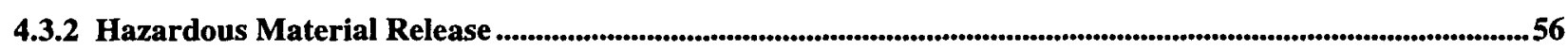

5.0 DECOMMISSIONING OPERATIONS............................................................ 57

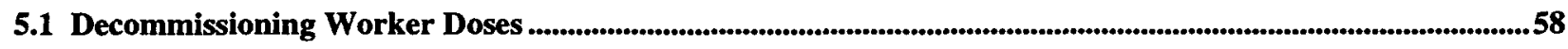

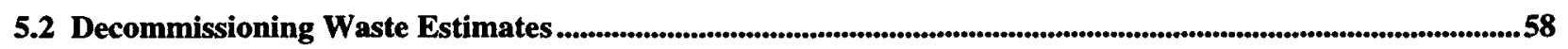

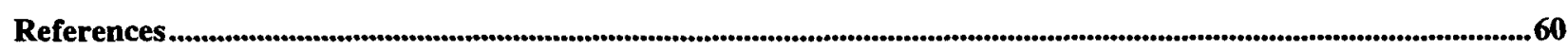




\section{Tables}

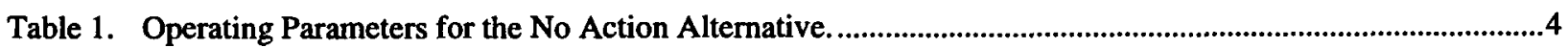

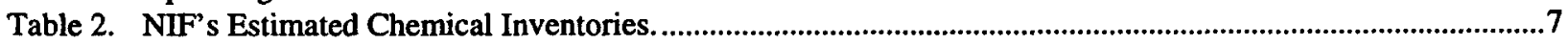

Table 3. Bounding Annual Particulate Inventories in the Target Chamber...............................................................9

Table 4. NIF LTAB Estimated Maximum Mobilizable Radionuclide Inventories for the No Action Alternative.......11

Table 5. Neutron-induced Radioactivity Produced in Target Bay Air, Based on 1200-MJ/yr Fusion Yield...............13

Table 6. Estimated Annual Energy Requirements for the National Ignition Facility ....................................14

Table 7. Projected NIF Water Use and Sewer Discharges. ...................................................................................14

Table 8. Water and Wastewater Utility Capacity at Lawrence Livermore National Laboratory. ................................14

Table 9. Annual Emissions From National Ignition Facility Operation at Lawrence Livermore National

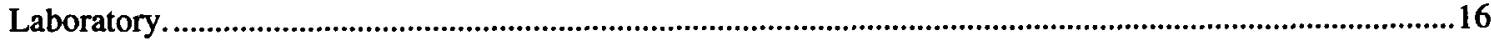

Table 10. Routine Radiological Releases from NIF.

Table 11 National Ignition Facility Waste Estimates for Low-Level, Mixed, and Hazardous Wastes (Per Year of National Ignition Facility Operation).

Table 12. NIF LTAB Estimated Maximum Radionuclide Inventories Released under Severe Accident Conditions....28

Table 13. Summary of More Significant Solvent and Decontamination Solution Inventories......................................31

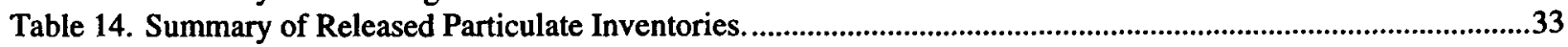

Table 15. Operating Parameters for Reduced Action Alternative..........................................................................36

Table 16. Neutron-Induced Radioactivity Produced in Target Bay Air, Based on 800-MJ/yr Fusion Yield.................37

Table 17. Routine Radiological Releases from NIF for the Reduced Action............................................................37

Table 18. National Ignition Facility Waste Estimates for Low-Level, Mixed, and Hazardous Wastes (Per Year) for Reduced Option.

Table 19. Operating Parameters for the Proposed Action Alternative..........................................................................40

Table 20. Bounding Annual Particulate Inventories in the Target Chamber for the Proposed Action Alternative.........41

Table 21. Estimated Maximum Mobilizable Radionuclide Inventories for the Proposed Action Alternative................43

Table 22. Annual Additional Routine Radioactive Airborne Emissions for Proposed Action (Fission Products). 1.2-gram HEU/target: 2E16 fissions per 20-MJ shot, 60 shots per year.

Table 23. National Ignition Facility Waste Estimates for Low-Level, Mixed, and Hazardous Wastes (Per Year of National Ignition Facility Operation) for the Proposed Action Alternative..................................................51

Table 24. Possible Bounding Radiological Accident Source Terms for the Proposed Action Alternative ....................52

Table 25. Proposed Action Hazardous Materials Accident Source Term Due to Release of Particulate Inventories. ...56

Table 26. Estimated Quantities of Waste from Laser Decommissioning. ...............................................................59

Table 27. National Ignition Facility Target Area Low-Level Radioactive Waste Quantities from Decommissioning. 



\section{Introduction}

This report provides the baseline data from which the environmental impacts of bounding NIF operations can be assessed. Included are operations in the NIF Laser and Target Area Building (LTAB) and the Optics Assembly Building (OAB), (Buildings 581 and 681), and the Building 582 equipment building.

The NIF is an experimental laser fusion facility undergoing construction and commissioning at Lawrence Livermore National Laboratory. The LTAB, the main experimental building of the NIF, is where laser-driven experiments will be conducted. The LTAB consists of two laser bays, two optical switchyards, a target bay, target diagnostics areas, capacitor bays, mechanical equipment areas, control rooms, and operational support areas (see Figure 1). The LTAB provides an optically stable and clean environment and provides sufficient shielding against prompt radiation and residual radioactivity to meet the as low as reasonably achievable (ALARA) principle.

Housed in the LTAB is a 192-beam, neodymium glass laser, which will deliver laser light of the required frequency and energy to small fusion targets mounted in a $10-\mathrm{cm}-$ thick, 10-m-diameter aluminum alloy vacuum chamber. The target area provides all systems necessary to support the experiments: target chamber, target emplacement, target diagnostic inserters, support structures, environmental protection systems, and support systems. The target chamber confines the $\mathrm{x}$-rays and debris generated by each experiment; the shielding attenuates neutron and secondary radiation fluences to acceptable levels during shots producing neutron yield and further prevents unacceptable levels of induced activity. At the center of the chamber, a target will be precisely located by the target emplacement and positioning/alignment system. These systems are supported by electrical power conditioning, diagnostic computer control systems, utilities, and mechanical and auxiliary support systems. Environmental protection systems have been designed to meet key functional requirements, such as limiting tritium inventory and tritium release to the environment. These systems will be located adjacent to the target bay and will consist of tritium processing systems (i.e., recovery of tritium onto dryer beds for later disposal or recycling), cleaning and decontamination systems, radiation and tritium monitoring systems, and waste packaging and characterization capabilities.

The $O A B$ includes optics processing equipment and general cleaning and precision cleaning equipment. Cleaned specialty optical components are assembled into their frames in the OAB (see Figure 2). These Line Replaceable Units (LRUs) are then placed into canisters for transport and insertion into the laser system.

LLNL has additional facilities that will support NIF in a number of areas, including the Central Plant, target fabrication, development support laboratories, and optics processing areas. The general scope of operations and research and development work will not change in these facilities, and their environmental impacts will be addressed in other sections of the LLNL Sitewide Environmental Impact Statement (EIS). 
This document summarizes and updates the baseline data for assessing the environmental impacts of continuing construction, commissioning, operation, and decommissioning of the National Ignition Facility.

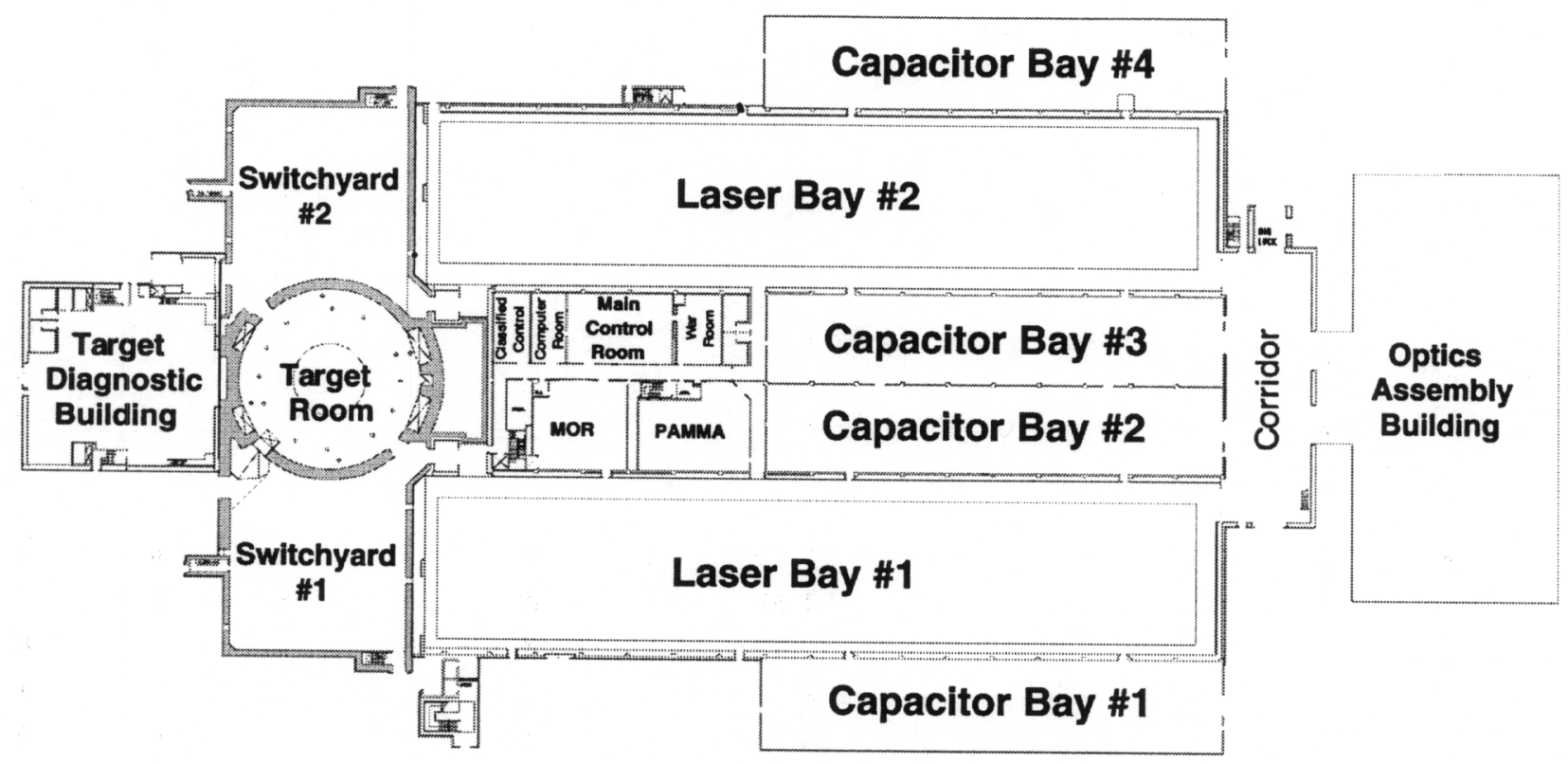

Figure 1. NIF LTAB layout. 


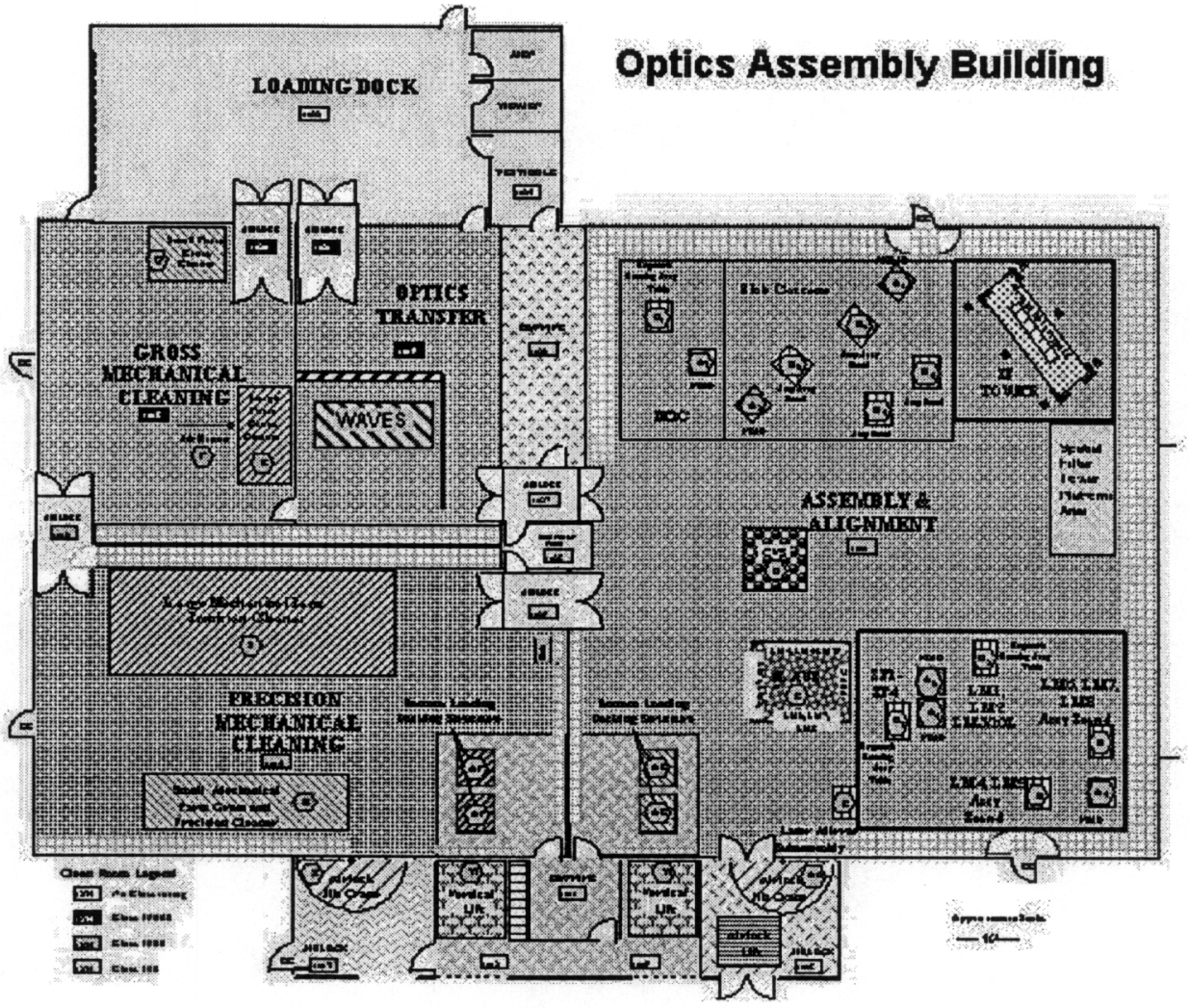

Figure 2. NIF OAB Layout 


\section{No Action Alternative}

\subsection{NIF Operation Under the No Action Alternative}

NIF research operations are expected to commence in CY2004 and continue for a total project life of about 30 years. Operations will begin with one bundle of laser beams and build up over time, as bundles are commissioned. Full operations will involve 24 bundles/ 192 beams and be capable of delivering $1.8 \mathrm{MJ}$ of $0.35-\mu \mathrm{m}$ light to Target Chamber Center (TCC) after the Project planned completion in 2008. The NIF facility operations comprise several stages:

- Start-up experiments to activate core diagnostics and to validate laser performance.

- Hohlraum tuning experiments to attain minimum asymmetry in $x$-ray drive (indirect drive only, laser symmetry experiments for direct drive).

- Cryogenic pre-ignition experiments for detailed study of capsule implosions.

- User experiments for weapons physics, weapons effects, and other user groups.

- Ignition experiments.

- Ignited burn experiments to obtain basic data for inertial confinement fusion energy development, basic scientific research on high-density plasmas, and research relative to various military-related applications.

The maximum number of shots per year is 750 shots due to scheduled maintenance, time needed to cool down amplifiers, and stayout time after shots producing significant neutron yield. A bounding year of NIF operations has been identified and is summarized in Table 1, below.

Table 1. Operating Parameters for the No Action Alternative.

\begin{tabular}{ll}
\hline \multicolumn{1}{c}{ Operating Parameter } & \multicolumn{1}{c}{ Value } \\
\hline Maximum shot yield & $20 \mathrm{MJ}$ maximum planned; 45 MJ maximum \\
& theoretical \\
Total yield & $1,200 \mathrm{MJ} / \mathrm{yr}$ \\
Tritium throughput & $1,750 \mathrm{Ci} / \mathrm{yr}$ \\
Maximum tritium inventory & $500 \mathrm{Ci}$ \\
Tritium effluent & $30 \mathrm{Ci} / \mathrm{yr}$ \\
\hline
\end{tabular}

Full NIF operations will produce the maximum annual yield of $1200 \mathrm{MJ}$. There are five main areas of investigation for the NIF-ignition physics, weapons physics, weapons effects, inertial fusion energy (IFE), and basic science and technology. Classes 
of experiments from all five of the main areas of investigation are assumed for the bounding year.

\subsubsection{Non-Radiological Materials Use and Inventories}

The main non-radiological materials at NIF include miscellaneous solvents and cleaning chemicals, decontamination process materials, fluids in electrical equipment, and materials that are part of, or placed into, the target chamber. Mobilizable material that may be dispersed during an accident is created inside the target chamber, as ablated or vaporized first-wall, target shell debris, hohlraum, target positioner and support systems, diagnostic windows, and debris shields. This in-chamber particulate generation is discussed in more detail in the next section. Other materials needed to support NIF operations include inert gases (argon) for laser operations, liquid nitrogen for cryopumps, and other chemicals for general use. Some of these materials will be regularly consumed (e.g., wipe cleaning solvents); others may be expended and require replacement during the lifetime of NIF (e.g., decontamination solutions). These materials will then become part of the waste stream. Waste is discussed in greater detail in Section 2.2.6.

A summary of non-radiological materials expected to be used in NIF is provided in Table 2. Listed are maximum facility inventories.

NIF uses volatile organic solvents for lens cleaning and other wipe cleaning operations in the cleanroom environment. These include ethanol, acetone, and isopropanol. The use of such solvents is limited to 400 gallons/year by a Bay Area Air Quality Management District (BAAQMD) air permit (S-2121). Based on experience to date, it is estimated that the annual solvent usage will not approach 400 gallons/year. The usage of solvents for wipe cleaning has been greatly reduced by using dilute aqueous solvent solutions, steam-cleaning, dry-wiping, and other techniques.

Decontamination processes require a working inventory of cleaning agents. An onsite inventory to replenish working solutions is also needed. This includes phosphoric acid, nitric acid, and sodium hydroxide. These will be utilized in cleaning solutions in the decontamination area.

The power for the NIF laser is supplied by a discharging bank of capacitors. These contain castor oil, which is nontoxic. The power supply system contains 960 spark-gap switches, and these create small amounts of ozone and NOx upon discharge. The sparkgap switches are within the capacitor modules in the capacitor bays, which are exclusion areas during operations. Small amounts of NOx and ozone may also be created in the amplifiers as a result of shorts and arcing during shots.

The power conditioning units (PCU) used in support of the preamplifier modules (PAMs) each have four ignitron switches. Each ignitron will contain $0.018 \mathrm{~L}$ of mercury. With 192 switches, this makes a total of $3.5 \mathrm{~L}$ of mercury at the facility, as listed in Table 2. Each of the 48 PAMs has a dedicated, closed ethylene glycol/deionizeddemineralized water coolant loop for thermal control. 
Throughout the LTAB, there is the need for small quantities of various cleaners, oils, and miscellaneous other materials. These are not specifically listed in Table 2, as the quantities and hazard level is bounded by other materials listed.

The Optics Assembly Building has a small inventory of chemicals primarily used for cleaning. The main agent (Brulin $815 \mathrm{GD}$ ) used contains no hazardous ingredients and is generally approved for discharge to the sewer. The other chemicals listed are stored in small quantities at the facility. Acetone and ethanol are used only for occasional spot cleaning. Clean room wipes presaturated with $9 \%$ isopropanol in de-ionized water are used more frequently, but also in small quantities. 
Table 2. NIF's Estimated Chemical Inventories.

\begin{tabular}{|c|c|c|c|}
\hline Chemical & Source & Quntity & Exposure Criteriaa \\
\hline Acetone & Cleaners, etc., & $\begin{array}{l}210 \mathrm{~L}(165 \mathrm{~kg}) \\
+ \text { OAB } 13 \mathrm{~L}(10 \mathrm{~kg})\end{array}$ & $500 \mathrm{ppm} \mathrm{ACGIH}^{\mathrm{b}}$ \\
\hline Alcohol, ethyl (ethanol) & Cleaners, etc., & $\begin{array}{l}256 \mathrm{~L}(239 \mathrm{~kg}) \\
+ \text { OAB } 10.7 \mathrm{~L} \\
(10 \mathrm{~kg})\end{array}$ & 1000 ppm (ACGIH) \\
\hline Alcohol, isopropyl & Cleaners, etc., & $\begin{array}{l}224 \mathrm{~L}(16.2 \mathrm{~kg}) \\
+ \text { OAB } 40 \mathrm{~L}(20 \mathrm{~kg}) \\
\text { and } 10 \mathrm{~kg} \text { (wipes) }\end{array}$ & $200 \mathrm{ppm}(\mathrm{ACGIH})$ \\
\hline Argon & Beam tubes & $10,100 \mathrm{~kg}$ & - \\
\hline Castor oil (ricinus oil) & $\begin{array}{l}\text { Dielectric fluid in } \\
\text { capacitors }\end{array}$ & $227 \mathrm{~kL}$ & - \\
\hline $\begin{array}{l}\text { Decon Acid Bath } \\
\text { Nitric Acid + Phosphoric }\end{array}$ & $\begin{array}{l}\text { First wall } \\
\text { decontamination }\end{array}$ & $\begin{array}{l}8000 \mathrm{~L}(10624 \mathrm{~kg}), \\
2520 \mathrm{~kg} \text { as } \mathrm{HNO}_{3}\end{array}$ & $\begin{array}{l}2 \mathrm{ppm} \mathrm{HNO}_{3} \\
(\mathrm{ACGIH})\end{array}$ \\
\hline Acid (5 M each) & & $3920 \mathrm{~kg}$ as $\mathrm{H}_{3} \mathrm{PO}_{4}$ & $\begin{array}{l}1 \mathrm{mg} / \mathrm{m}^{3} \mathrm{H}_{3} \mathrm{PO}_{4} \\
(\mathrm{ACGIH})\end{array}$ \\
\hline Ethylene glycol & PAM coolant & $170 \mathrm{~kg}$ & $\begin{array}{l}100 \mathrm{mg} / \mathrm{m}^{3} \text { (ACGIH) } \\
\text { (ceiling) }\end{array}$ \\
\hline Hydrogen Peroxide & Water disinfectant & $100 \mathrm{~L}$ & 1 ppm(NIOSH) ${ }^{d}$ \\
\hline Mercury, metallic & 192 PAM switches & $3.5 \mathrm{~L}^{\mathrm{c}}(47 \mathrm{~kg})$ & $0.025 \mathrm{mg} / \mathrm{m}^{3}(\mathrm{ACGIH})$ \\
\hline Methlyene chloride & Cleaners, etc., & $4 \mathrm{~L}(1.32 \mathrm{~kg})$ & 50 ppm (ACGIH) \\
\hline $\begin{array}{l}\text { Nitric Acid ( } 70 \% \\
\text { solution) }\end{array}$ & $\begin{array}{l}\text { Supply on hand for } \\
\text { replenishing decon } \\
\text { solution }\end{array}$ & $\begin{array}{l}400 \mathrm{~L}(540 \mathrm{~kg}) \\
420 \mathrm{~kg} \text { as } \mathrm{HNO}_{3}\end{array}$ & $1 \mathrm{ppm}(\mathrm{ACGIH})$ \\
\hline Nitrogen & $\begin{array}{l}\text { Cleaning propellant, } \\
\text { dry box purging, beam } \\
\text { tubes, amplifier } \\
\text { cooling, cryogen }\end{array}$ & $96,000 \mathrm{~kg}$ & - \\
\hline Particulate & $\begin{array}{l}\text { Target chamber } \\
\text { materials }\end{array}$ & See next section & \\
\hline $\begin{array}{l}\text { Phosphoric Acid ( } 87 \% \\
\text { solution) }\end{array}$ & $\begin{array}{l}\text { Supply on hand for } \\
\text { replenishing decon } \\
\text { solution }\end{array}$ & $\begin{array}{l}400 \mathrm{~L}(691 \mathrm{~kg}) \\
639 \mathrm{~kg} \text { as } \mathrm{H}_{3} \mathrm{PO}_{4}\end{array}$ & $1 \mathrm{mg} / \mathrm{m}^{3}(\mathrm{ACGIH})$ \\
\hline Sodium Hydroxide (5 M) & Decon (caustic bath) & $\begin{array}{l}8000 \mathrm{~L}(8320 \mathrm{~kg}) \\
1600 \mathrm{~kg} \text { as } \mathrm{NaOH}\end{array}$ & $\begin{array}{l}2 \mathrm{mg} / \mathrm{m}^{3} \text { (ACGIH) } \\
\text { (ceiling) }\end{array}$ \\
\hline $\begin{array}{l}\text { Sodium Hydroxide ( } 50 \% \\
\text { solution) }\end{array}$ & $\begin{array}{l}\text { Supply on hand for } \\
\text { replenishing decon } \\
\text { solution }\end{array}$ & $\begin{array}{l}400 \mathrm{~L}(612 \mathrm{~kg}) \\
306 \mathrm{~kg} \text { as } \mathrm{NaOH}\end{array}$ & $\begin{array}{l}2 \mathrm{mg} / \mathrm{m}^{3} \text { (ACGIH) } \\
\text { (ceiling) }\end{array}$ \\
\hline Toluene & Optics prep & $18 \mathrm{~L}(16 \mathrm{~kg})$ & $50 \mathrm{ppm}(\mathrm{ACGIH})$ \\
\hline Xylene & Optics prep & $18 \mathrm{~L}(16 \mathrm{~kg})$ & $100 \mathrm{ppm}$ (ACGIH) \\
\hline
\end{tabular}

\footnotetext{
a All criteria are 8-h time weighted averages (TLV-TWA), unless otherwise stated.

b ACGIH: American Conference of Governmental Industrial Hygienists.

c Single ignitron inventories are approximately $0.018 \mathrm{~L}(245 \mathrm{~g})$.

d National Institute for Occupational Safety and Health.
} 


\subsubsection{Particulate Production}

During a shot, the $1.8 \mathrm{MJ}$ of laser energy will be deposited on the target by the 192 beams precisely placed on the target at its predesignated location. The result is general vaporization of the target, emission of $x$-rays, and for targets containing deuterium/ tritium, a release of neutrons. The $x$-rays emitted can create a sufficiently high fluence on nearby components, such as the target positioner or diagnostic manipulators, to induce yet further ablation from these surfaces. X-rays may also ablate a thin layer of material from the protective first-wall panels and the debris shields. Unconverted laser light (mainly $1.05-\mu \mathrm{m}$ light) is absorbed on the protective first-wall panels and induces ablation of this surface. Structures close-in to the target can undergo melting during high-yield shots. The state of the ablated material after a shot is expected to be small pieces of debris and fine particulate. Conservatively, for the purpose of this analysis, it was assumed that all the ablated material will exist as fine particulate (easily made airborne).

Based on the expected experimental campaign for NIF, an integral quantity of annual target material use and subsequent particulate generation have been calculated. Based on the incident laser energy, distance from target chamber center, angle, and laser energy and/or yield of the shot, ablated thicknesses of relevant surfaces were estimated, scaling from experimental data and other applicable radiationhydrodynamic calculations. These values were multiplied by the exposed crosssectional areas to give a total amount of ablated material per shot. The material ablated from the first wall due to unconverted light was calculated based on the incident unconverted laser light fluence. The particulate generated from target materials was added to the particulate generated due to ablation of diagnostics, first wall, and debris shields. Table 3 presents the bounding annual amount of particulate material expected to be produced from NIF Operations. This represents the maximum facility inventory expected to be generated in any given year. This is based on current plans for experiments and their associated targets and diagnostics and provides the most reasonable and conservative estimate that can be made at this time.

The in-chamber inventories provided in Table 3 are conservative estimates of the amount of material that would be present as particulates at the end of one year. More frequent than annual chamber cleaning would reduce the inventory. The remainder of the unablated first-wall, debris shield, diagnostic, etc., components is solid structure and is not vulnerable to release under any credible circumstances. 
Table 3. Bounding Annual Particulate Inventories in the Target Chamber.

\begin{tabular}{cc}
\hline Material & $\begin{array}{c}\text { Maximum Inventory } \\
\text { (g) }\end{array}$ \\
\hline $\mathrm{Al}$ & $2.1 \mathrm{E} 3$ \\
$\mathrm{Au}$ & $4.0 \mathrm{E} 1$ \\
$\mathrm{Be}$ & $1.6 \mathrm{E} 0$ \\
$\mathrm{Cu}$ & $1.7 \mathrm{E} 2$ \\
$\mathrm{Dy}$ & $2.1 \mathrm{E} 0$ \\
$\mathrm{Fe}$ & $2.6 \mathrm{E} 2$ \\
$\mathrm{Gd}$ & $2.0 \mathrm{E} 1$ \\
$\mathrm{Ge}$ & $2.0 \mathrm{E} 1$ \\
$\mathrm{~Pb}$ & $3.0 \mathrm{E} 1$ \\
$\mathrm{Sc}$ & $7.0 \mathrm{E} 0$ \\
$\mathrm{Si}$ & $5.0 \mathrm{E} 2$ \\
$\mathrm{Ta}$ & $2.9 \mathrm{E} 1$ \\
$\mathrm{Ti}$ & $1.0 \mathrm{E} 1$ \\
$\mathrm{U}$ (depleted) & $5.0 \mathrm{E} 0$ \\
$\mathrm{~B} 4 \mathrm{C}$ & $1.1 \mathrm{E} 3$ \\
\hline
\end{tabular}

\subsubsection{Radioactive Materials Use/Production}

During certain fusion experiments, each of the 192 laser beams will be directed to and focused on a target containing fusion fuel (a deuterium-tritium mixture). The fusion experiment will emit neutrons, energetic particles, debris, and $x$-rays. The energetic particles, debris, and $\mathrm{x}$-rays will be confined by the 5-m inner-radius aluminum alloy target chamber. Most neutrons and secondary radiation will travel through the target chamber and local shielding structure before being adequately attenuated by concrete walls. Some neutrons will activate the target chamber, structures and components in the target bay, gases in the target bay air, and concrete and rebar in the walls, roof, and floor. All materials in the target bay are subject to neutron activation. Most of the unburned tritium is expected to be exhausted to the tritium processing system, while a small amount will be adsorbed onto the target chamber wall and other items entrant in the target chamber.

Radioactivity will be present at the LTAB in the following forms:

Tritium: ${ }^{1}$

In-process tritium inventories include any accumulation of tritium in the facility that is releasable and quantifiable, and that is part of the tritium handling cycle in NIF. This includes inventories in locations such as targets (and associated hardware, e.g., target

1 Dispersed inventories, such as those potentially found in interconnecting piping, on interior surfaces of components, as surface contamination on diagnostics and target positioner, etc., are not included in the $500-\mathrm{Ci}$ inventory limit. 
stalk), cryopumps, molecular sieve, and decontamination systems; it does not include residual surface contamination that is chemically or physically bound.

Neutron activation products:

- As particulate (or debris) located in the target chamber, the cleaning system discharge, and decontamination gloveboxes.

- As activation products in the target bay structures (including the target chamber, shielding, space frame, optics, beam tubes, catwalk, concrete walls/rebar, etc.).

- As activated gases in the target bay atmosphere and beam tubes.

\section{Other forms:}

- Radioactive target materials, such as depleted uranium (DU).

Tritium inventories at the various possible locations will vary during facility operation and will be controlled such that the in-process tritium inventory within the facility totals no more than $500 \mathrm{Ci}$. The annual tritium throughput will be limited to $1,750 \mathrm{Ci} / \mathrm{yr}$.

Tritium will arrive at the facility in individual targets, containing up to $5 \mathrm{Ci}$ each ( $2 \mathrm{Ci}$ in the capsule and up to $3 \mathrm{Ci}$ in the associated hardware), except in the event that direct drive is implemented, in which case each target would contain up to $70 \mathrm{Ci}$ (up to $35 \mathrm{Ci}$ in the capsule and up to $35 \mathrm{Ci}$ in the support structure). After a shot, unburned tritium will be exhausted to the vacuum system and then processed and retained in the collection system. Components within the target chamber (e.g., first-wall panels, debris shields) will be routinely decontaminated to remove any tritium and activated material. The tritium and activated material will be transferred to the decontamination system and to the waste stream. As noted above, an administrative program will be in place for inventory control to ensure that the total facility in-process tritium inventory does not exceed $500 \mathrm{Ci}$.

Estimated particulate generation was provided in the previous section. As this material is exposed to neutrons from yield shots, it will become radioactive. These materials will accumulate in the target chamber until the scheduled cleanup (this was conservatively assumed to be annually). During clean-up and decontamination, the particulate will be transferred to the decontamination system and waste stream. The cleaning processes are described in a subsequent section.

Table 4 lists the prominent nuclides expected from activated particulate in the chamber. The total inventory of activated, mobilizable particulate created in the chamber will be quite small, but it is included here for completeness. As noted earlier, activated particulate will be transferred to the decontamination systems and waste streams. However, since these are mostly short-lived species, the maximum inventories would be found in the target chamber shortly after the last shot and well before cleanup. By the time cleaning occurs or components are removed, the radioactive 
particulate inventory would have decayed to much smaller activities. The inventories in Table 4 are maximum inventories. They correspond to a final 45-MJ-yield shot, ending one year of shots with 1200-MJ total yield. Shots of this magnitude (45 MJ) are not scheduled as part of the normal experimental plan. However, $45 \mathrm{MJ}$ is the maximum theoretical yield that could be obtained. The 45-MJ inventories are used here to bound all inventories of activated material.

Solid structures and components within the target bay will also become activated. Activation inventories in the target chamber structure, shielding, space frame, catwalk or walls/roof/floors, are not included in Table 4, as these inventories are contained within structures and are not releasable under any credible circumstances. They do not present a hazard outside the facility because of the shielding. However, workers will be exposed during maintenance activities when they enter the target bay to perform a task, or when they handle an activated component. Exposures from operational activities are discussed in Section 2.2.4.

During DT fusion shots, the NIF will generate neutron activation products in the target bay air and beam tube gases. In Table 4, estimated maximum quantities of activated gases generated during a single 45-MJ yield shot are provided (note that no accumulation occurs because of the short half-lives of the radionuclides and because of the fresh air provided to the target bay). The total annual production of radioactive gases produced in the target bay air for $1200 \mathrm{MJ} / \mathrm{yr}$ is provided in Table 5. These activated target bay gases will be released through the elevated release point, $35 \mathrm{~m}$ above ground, and should be used to assess the routine impact from airborne radiological emissions from NIF. The release point is $1.1 \mathrm{~m}$ in diameter, and gases will exit at $7.3 \mathrm{~m} / \mathrm{s}(1 \% \mathrm{vol} / \mathrm{min})$. The Maximally Exposed Individual (MEI) is expected to be located at the Veterinary facility, $400 \mathrm{~m}$ from the elevated release point.

Table 4. NIF LTAB Estimated Maximum Mobilizable Radionuclide Inventories for the No Action Alternative.

\begin{tabular}{cc}
\hline Isotope & Quantity Ci \\
\hline Total tritium & 500 \\
Activated particulates & \\
Na-24 & $4.0 \mathrm{E}-1$ \\
Mn-56 & 1.3 \\
Co-60 & $7.4 \mathrm{E}-2$ \\
Mn-54 & $1.4 \mathrm{E}-1$ \\
Sc-48 & $3.6 \mathrm{E}-2$ \\
Fe-55 & $7.1 \mathrm{E}-1$ \\
Sc-46 & $4.6 \mathrm{E}-2$ \\
Ca-45 & $1.0 \mathrm{E}-1$ \\
Sc-44 & $2.0 \mathrm{E}-1$
\end{tabular}
2 After one year of operation without clean-up; corresponds to a final 45-MJ shot, ending a year with $1200 \mathrm{MJ}$ total
yield. 


$\begin{array}{cc}\text { Ta-182 } & 2.5 \mathrm{E}-2 \\ \mathrm{Sc}-44 \mathrm{~m} & 6.4 \mathrm{E}-2 \\ \mathrm{Gd}-153 & 2.5 \mathrm{E}-2 \\ \mathrm{Ni}-65 & 2.0 \mathrm{E}-1 \\ \mathrm{Cu}-64 & 1.5 \\ \mathrm{Co}-62 \mathrm{~m} & 1.6 \mathrm{E}-1 \\ \mathrm{~Pb}-203 & 1.6 \mathrm{E}-2 \\ \mathrm{Sc}-47 & 2.4 \mathrm{E}-2 \\ \mathrm{~K}-42 & 1.8 \mathrm{E}-2 \\ \mathrm{Ga}-72 & 2.8 \mathrm{E}-3 \\ \mathrm{Hf}-181 & 2.8 \mathrm{E}-3 \\ \mathrm{Gd}-159 & 8.6 \mathrm{E}-2 \\ \mathrm{Cr}-51 & 4.7 \mathrm{E}-2 \\ \mathrm{Dy}-159 & 4.2 \mathrm{E}-3 \\ \text { Eu-156 } & 7.9 \mathrm{E}-4 \\ \mathrm{Ni}-63 & 8.8 \mathrm{E}-3\end{array}$

Depleted uranium ${ }^{3}$

$\begin{array}{ll}\text { U-234 } & 8.6 \mathrm{E}-7 \\ \mathrm{U}-235 & 4.0 \mathrm{E}-8 \\ \mathrm{U}-238 & 1.6 \mathrm{E}-6\end{array}$

Activated gases 4

Target bay air:

H-3

$1.6 \mathrm{E}-4$

$\mathrm{N}-13 \quad 1.9 \mathrm{E} 1$

$\mathrm{N}-16 \quad 3.2 \mathrm{E} 3$

$\mathrm{S}-37 \quad 4.2 \mathrm{E}-1$

$\mathrm{Cl}-40 \quad 2.4$

Ar-41 1.6

C-14 4.9E-5

Argon in beam tubes:

H-3

$3.4 \mathrm{E}-8$

S-35

$3.4 \mathrm{E}-6$

Ar-37

8.7E-4

Ar-39

$1.2 \mathrm{E}-4$

Ar-41

3 Depleted uranium would be used only in non-yield shots and is therefore not considered "activated" (and no fission products are produced). It is already slightly radioactive (half-life of U-238 (dominant isotope) is 4.5E9 yrs). The assumed composition is: $99.64 \%$ U-238, $0.36 \%$ U-235, and $0.0028 \%$ U-234. The quantities listed correspond to the maximum use over a year of $5 \mathrm{~g}$.

4 After a single 45-MJ shot. 
Table 5. Neutron-induced Radioactivity Produced in Target Bay Air, Based on 1200-MJ/yr Fusion Yield.

\begin{tabular}{ccc}
\hline $\begin{array}{c}\text { Nuclide } \\
\text { produced }\end{array}$ & Nuclide half-life & $\begin{array}{c}\text { Production } \\
\text { (Ci/y) }\end{array}$ \\
\hline H 3 & $12.33 \mathrm{y}$ & $4.32 \mathrm{E}-03$ \\
C 14 & $5730 \mathrm{y}$ & $1.30 \mathrm{E}-03$ \\
N 13 & $9.99 \mathrm{~min}$ & $5.12 \mathrm{E}+02$ \\
N 16 & $7.13 \mathrm{~s}$ & $8.41 \mathrm{E}+04$ \\
S 37 & $5.06 \mathrm{~min}$ & $1.11 \mathrm{E}+01$ \\
C 40 & $1.42 \mathrm{~min}$ & $6.41 \mathrm{E}+01$ \\
$\mathrm{Ar} 41$ & $1.83 \mathrm{~h}$ & $4.19 \mathrm{E}+01$ \\
\hline
\end{tabular}

\subsection{Environmental Impacts During Routine Operations}

Environmental impacts of NIF operations include energy use, water use and wastewater discharge, air emissions, worker exposures, and waste generation. Nonradiological air emissions result primarily from combustion equipment and from solvent cleaning. Radiological air emissions result from activated gases produced during yield shots and from tritium emissions during maintenance activities. Waste generation results from cleaning processes and from replacement of used or damaged equipment. Waste is covered in Section 2.2.6.

\subsubsection{Energy Use During Operations}

NIF will use energy to operate plant equipment to support basic operations. This includes operation of the HVAC system, chilled and heated water systems, lighting, etc., and operation of the laser equipment (e.g., charging of capacitors, operation of the control room, laser alignment sources, etc.). NIF energy use is comprised of electrical use, natural gas consumption, and diesel fuel consumption. Estimated energy requirements are summarized in Table 6.

The original NIF electric power requirement was established to be 14 megawatts (MW) by the NIF architecture/engineering firm Parsons. This estimate has been increased by $7 \%$ to $15 \mathrm{MW}$, primarily because of the addition of a new "Clean Dry Air" system. The power would be utilized continuously for 8760 hours/year for a total energy consumption of 131,400 MW hours/year (4.73 E08 MJ/year). This is higher than the estimate in the March 1999 Supplement Analysis for Continued Operation of LLNL and SNL (DOE/EIS-0157-SA-01), which described an increase of 97,700 MW hours/year by the year 2002. This estimate was primarily based on NIF energy requirements, but included other facilities such as the TeraScale Facility (TSF).

NIF standby generators are supported by diesel fuel. These generators are needed only to support key systems in the event of loss of primary power. These generators 
will be started up and tested/maintained regularly $(\sim 10 \mathrm{hr} / \mathrm{yr})$, but since they normally will not be operational, fuel consumption will be low.

Table 6. Estimated Annual Energy Requirements for the National Ignition Facility.

\begin{tabular}{lllc}
\hline \multicolumn{1}{c}{ Facility } & \multicolumn{1}{c}{ Use } & Fuel Type & $\begin{array}{c}\text { Annual Energy } \\
\text { Consumption }\end{array}$ \\
\hline $\begin{array}{l}\text { NIF Laser and Target } \\
\text { Area Building }\end{array}$ & $\begin{array}{l}\text { Ventilation, cooling, air conditioning } \\
\text { and domestic hot water, laser } \\
\text { operations }\end{array}$ & Electric & $4.73 \mathrm{E} 8 \mathrm{MJ}$ \\
$\begin{array}{l}\text { NIF Laser and Target } \\
\text { Area Building }\end{array}$ & \begin{tabular}{l} 
Stand-by power \\
\hline
\end{tabular} & Diesel & $1,800 \mathrm{~L}$ \\
\hline
\end{tabular}

\subsubsection{Water Use During Operations}

Water is used for a variety of operations, including boilers, cooling towers, domestic use, landscape irrigation, washing and fire hydrant testing. Some of the water is evaporated to the atmosphere, while other water is discharged to the sanitary sewer or storm drain, as appropriate. A water balance for LLNL has been developed from several years of experience, which provides the discharge pathways for various water uses. The LLNL water balance was used to estimate the water/wastewater pathways for NIF. A summary of projected water use and discharge quantities for NIF is provided in Table 7. The related LLNL utility capacities are provided in Table 8.

Table 7. Projected NIF Water Use and Sewer Discharges.

\begin{tabular}{lcc}
\hline \multicolumn{1}{c}{ Water Use Type } & $\begin{array}{c}\text { Water usage } \\
\text { kgal/day }\end{array}$ & $\begin{array}{c}\text { To sewer } \\
\text { kgal/day }\end{array}$ \\
\hline Sanitary & 6.2 & 4.4 \\
Process & 4.0 & 3.9 \\
Washing & 1.0 & 0.90 \\
Landscape irrigation & 8.0 & 0.0 \\
De-ionized water & 0.75 & 0.34 \\
Fire hydrant testing & 0.05 & 0.0 \\
Total (kgal/day) & 20.0 & 9.54 \\
Total (ML/year) & 27.6 & 13.2 \\
\hline
\end{tabular}

Table 8. Water and Wastewater Utility Capacity at Lawrence Livermore National Laboratory.

\begin{tabular}{lcccc}
\hline Utility System & Current Usage & NIF Requirement & $\begin{array}{c}\text { Projected Usage, } \\
\text { Including NIF }\end{array}$ & $\begin{array}{c}\text { Current } \\
\text { Capacity }\end{array}$ \\
\hline Water supply (MLY) & 981 & 27.6 & 1009 & 3,980 \\
Wastewater treatment (MLY) & 354 & 13.2 & 367 & 2,340 \\
\hline
\end{tabular}




\subsubsection{Non-Radiological Emissions During Operations}

As described in Section 2.1.1, some non-radiological hazardous materials will be present at NIF. Routine emissions of these types of materials is expected from operation of spark gap switches, wipe cleaning, and occasional use or maintenance/ testing of the standby generators.

The power for the NIF laser is supplied by a discharging bank of capacitors. The power supply system contains 960 spark-gap switches, and these create incidental amounts of ozone and NOx upon discharge.

NIF uses volatile organic solvents for lens cleaning and other wipe cleaning operations in the cleanroom environment. These include ethanol, acetone, and isopropanol. The use of such solvents is limited to 400 gallons/year, by a BAAQMD air permit (S-2121). Based on experience to date, it is estimated that the annual solvent usage will not approach 400 gallons/year. However, 400 gallons was used as a bounding quantity in Table 9 . The usage of solvents for wipe cleaning has been greatly reduced by using dilute aqueous solvent solutions, steam-cleaning, dry-wiping, and other techniques.

The U.S. Environmental Protection Agency (EPA) has set National Ambient Air Quality Standards (NAAQS) to protect public health, and the State of California has its own sets of standards, that are generally more stringent than the federal standards. Air emissions are discussed below in terms of the federal and state "criteria air pollutants," which are ozone, carbon monoxide, nitrogen dioxide, sulfur oxides, particulate matter and lead. NIF generates criteria air pollutants during operation of the standby generators. NIF has two standby diesel generators, one of which is 754 horsepower and other of which is 250 horsepower. In the unlikely event of a power outage, these generators would operate until the utility power is restored. Under normal conditions, the engines would be operated only for the purpose of maintenance and testing, for about 10 hours/year. Until recently, emergency standby generators were exempt from air permitting. The regulations were changed to require air permits, and existing generators (such as the two NIF generators) were "grandfathered" into the system of permitted sources. Air permits were received for the two generators in June, 2002. The new air permits allow for unlimited operation during a power outage. A power outage is unlikely, since LLNL obtains power from two separate power suppliers. Therefore, air emissions resulting from a power outage are not included in Table 9.

The projected NIF air emissions, based on the sources and assumptions discussed above, are summarized in Table 9. 
Table 9. Annual Emissions From National Ignition Facility Operation at Lawrence Livermore National Laboratory.

\begin{tabular}{|c|c|c|c|c|}
\hline Pollutant & $\begin{array}{c}2000^{\circ} \text { LLNL } \\
\text { Emissions } \\
(t / y r)\end{array}$ & $\begin{array}{c}\text { Projected NIF } \\
\text { Emissions } \\
(t / y r)\end{array}$ & $\begin{array}{c}2000 \text { LLNL } \\
\text { Emissions Plus NIF } \\
(t / y r)\end{array}$ & $\begin{array}{l}\text { NIF Percent of } 2000 \\
\text { LLNL Emissions }\end{array}$ \\
\hline $\begin{array}{l}\text { Particulate matter } \\
10 \text { microns or } \\
\text { smaller }\end{array}$ & 2.21 & 0.00419 & 2.21 & 0.19 \\
\hline $\begin{array}{l}\text { Volatile organic } \\
\text { compound }\end{array}$ & 7.87 & 1.18 & 9.05 & 15.0 \\
\hline Carbon monoxide & 5.58 & 0.0938 & 5.67 & 1.7 \\
\hline Nitrogen dioxide & 21.6 & 0.0758 & 21.7 & 0.35 \\
\hline Sulfur dioxide & 0.241 & 0.00165 & 0.242 & 0.68 \\
\hline Lead & Negligible & Negligible & Negligible & Negligible \\
\hline
\end{tabular}

'Year $\mathbf{2 0 0 0}$ data was available at the time of preparation of this report.

It has been air district policy to allow new equipment to be used for a reasonable "useful life," before it must be replaced or retrofitted to reduce emissions. Since the NIF emergency generators are relatively new, efficient units, it can be assumed that they will be allowed to be used for at least ten years without changes. It is possible that they will be allowed to be used without modification for the life of the facility, therefore no projections have been made for replacements to the existing combustion equipment. The relatively small amount of solvent usage will probably not be impacted by regulatory changes during the life of the facility. If emission reductions are required in the future, they might be accomplished by a "capture/control" process employing carbon adsorption. The air district generally applies a "cost-effectiveness" criterion in deciding if the additional controls are warranted, and it is unlikely that such controls would be deemed "cost-effective." It is more likely that solvent usage reductions will be accomplished voluntarily, as a result of pollution prevention/solvent substitution efforts.

Small amounts of environmental contaminants may be discharged to the sanitary sewer. Prior to any discharge, the effluent will be sampled and released only if it falls within the sewer discharge limits. If not, it will be handled as hazardous waste.

\subsubsection{Radiological Emissions and Worker Exposures During Routine Operations}

During routine NIF operations, experiments will result in normal atmospheric releases of small quantities of tritium and some radionuclides produced from activation of gases in the target bay air. Annual emissions of activated gases based on $1200 \mathrm{MJ} / \mathrm{yr}$ of yield are provided in Table 10. These are substantially smaller than the quantities actually produced (see Table 5) because of radioactive decay. It is also expected that up to $30 \mathrm{Ci} / \mathrm{yr}$ of tritium will be released during maintenance activities, when equipment is opened up or brought up to air. 
Table 10. Routine Radiological Releases from NIF.

\begin{tabular}{cccc}
\hline $\begin{array}{c}\text { Nuclide } \\
\text { produced }\end{array}$ & Nuclide half-life & $\begin{array}{c}\text { Production } \\
\text { (Ci/y) }\end{array}$ & $\begin{array}{c}\text { Emissions } \\
(\mathrm{Ci} / \mathrm{y})\end{array}$ \\
\hline Activated Air: & & & \\
H 3 & $12.33 \mathrm{y}$ & $4.32 \mathrm{E}-03$ & $4.32 \mathrm{E}-3$ \\
C 14 & $5730 \mathrm{y}$ & $1.30 \mathrm{E}-03$ & $1.30 \mathrm{E}-3$ \\
N 13 & $9.99 \mathrm{~min}$ & $5.12 \mathrm{E}+02$ & $6.78 \mathrm{E}+1$ \\
N 16 & $7.13 \mathrm{~s}$ & $8.41 \mathrm{E}+04$ & $1.53 \mathrm{E}+2$ \\
S 37 & $5.06 \mathrm{~min}$ & $1.11 \mathrm{E}+01$ & $7.93 \mathrm{E}-1$ \\
Cl 40 & $1.42 \mathrm{~min}$ & $6.41 \mathrm{E}+01$ & $1.29 \mathrm{E}+0$ \\
Ar 41 & $1.83 \mathrm{~h}$ & $4.19 \mathrm{E}+01$ & $2.62 \mathrm{E}+1$ \\
Tritium (releases & & & 30 \\
during & & & \\
maintenance) & & & \\
\hline
\end{tabular}

Personnel will be exposed to two sources of prompt radiation during NIF yield operations. First, personnel located within, or very close to, the facility will be exposed to some quantity of direct radiation. Direct radiation consists of both neutrons and gamma rays that are produced as the neutrons scatter and penetrate through the concrete shield wall and other materials. Second, personnel throughout the LLNL site will be exposed to some level of skyshine radiation. Skyshine radiation results from neutrons penetrating through the roof of the facility. These neutrons scatter off of the atmosphere above the facility. Some neutrons are scattered back down to the ground or to nearby buildings. Other neutrons result in the emission of gamma rays as they undergo nuclear reactions with air nuclei, and these gamma-rays reach personnel down on the ground.

To reduce the levels of direct and skyshine radiation exposure, the NIF shielding design consists of various components. This includes the target chamber gunite shielding (a $40-\mathrm{cm}$-thick layer of sprayable borated concrete with carbon steel reinforcing bars), target bay walls (1.83-m-thick concrete), target bay roof (1.37-m-thick concrete), switchyard walls (up to 1.14-m-thick concrete depending upon the specific location), and switchyard roofs ( $0.46-\mathrm{m}$-thick concrete). Due to the large number of penetrations through the target bay walls, additional shielding components have been added. These include the Mechanical Equipment Room walls (0.31-m-thick concrete), HVAC collimators (concrete tubes that allow airflow to pass while providing a tortuous path for neutrons and gamma-rays), and switchyard collimators (1.83-m-long extensions of the target bay walls on the switchyard side of the walls).

The skyshine dose at an air-ground interface as a function of distance from the center of the cylindrical target bay was calculated using 3-D Monte Carlo analysis. The 1.37-m-thick concrete target bay roof limits the skyshine dose at the nearest site boundary ( $350 \mathrm{~m}$ due east from the target bay) to less than $0.2 \mathrm{mrem} / \mathrm{yr}$ for all possible target illumination configurations. The dose at the site boundary is dominated by neutron skyshine (direct dose is small by comparison). 
Personnel within the NIF or "passing by" would also receive a prompt dose. Operations personnel, located in the Main Control Room, would receive a prompt dose of approximately $5 \mathrm{mrem} / \mathrm{yr}$. Those in the Diagnostics Building would receive about 3 $\mathrm{mrem} / \mathrm{yr}$, and those in the OAB would receive approximately $1 \mathrm{mrem} / \mathrm{yr}$. These prompt doses are based upon a 40-hour work week. Finally, someone moving past the facility would receive a direct dose of approximately $1 \mathrm{mrem} / \mathrm{yr}$ (assumes an occupancy of $1 / 16$ for walkways and roads as recommended by the National Council on Radiation Protection (NCRP, 1977).

The NIF target bay includes about fifty doorways to allow for adequate access of personnel and equipment. To maintain prompt doses at required levels, the entry points will be fitted with steel-enclosed, concrete shield doors. The doors will range from 0.31 to $1.83 \mathrm{~m}$ in thickness depending upon their elevation relative to the target chamber and the room to which they lead. Prompt doses immediately outside the shield doors in potentially occupied areas will be $<30 \mathrm{mrem} / \mathrm{yr}$.

During high-yield operations, tasks that must be performed within the NIF target bay or that involve handling of materials that have been inside the target bay during high-yield experiments will result in some level of radiation dose. The residual radiation intensity within the NIF target bay at any particular location will depend upon local and general activation in the room as well as the history of yield experiments. The highest intensity will be inside the $10-\mathrm{cm}$-thick, 5-m-radius aluminum alloy target chamber. At early times following a yield experiment, ${ }^{27} \mathrm{Mg}$ (half-life $=9.5$ minutes) and ${ }^{56} \mathrm{Mn}$ (2.6 hours) will dominate the residual dose rate. At times of 6 hours to 10 days after yield experiments, ${ }^{24} \mathrm{Na}$ (15 hours) will dominate. After decay times of more than 10 days, ${ }^{54} \mathrm{Mn}$ (312 days), ${ }^{60} \mathrm{Co}$ (5.3 years), and ${ }^{65} \mathrm{Zn}$ (244 days) will dominate. Occupational doses will be monitored, and maintenance activities and procedures will be organized to minimize occupational doses. Cost-benefit analyses will be performed, and auxiliary shielding will be utilized to ensure that worker doses are kept ALARA.

In addition, a worker dose would be incurred during routine maintenance and decontamination activities. This would include maintenance of elements of the tritium processing system and handling of contaminated/activated items, disassembling them (if needed), and processing them through the decontamination systems.

NIF worker exposure goals include:

- $<500 \mathrm{mrem} / \mathrm{yr}$ individual worker dose.

- $<15$ person-rem/yr cumulative worker dose.

Radiation exposure in radiologically controlled areas will be kept ALARA through facility and equipment design and administrative controls. Physical features, such as confinement, ventilation, shielding, and an elevated release point will be used as supplemental methods to control radiation exposure. A Measurement and Retrofit Plan has also been written to identify key locations in which prompt and residual doses shall be measured and facility additions and/or modifications that could be made if 
measurements suggest that radiation protection calculations underestimated those doses (Latkowski and Singh, 1997). An Auxiliary Shielding Plan has been written to identify potential uses for temporary neutron and gamma-ray shielding (Latkowski, 1998). Such shielding may prove beneficial in reducing worker doses to ALARA levels.

\subsubsection{Transport of Targets}

NIF targets are expected to come from two sources. Most of the targets will be provided from an onsite source, such as the LLNL Superblock. The other source would be Los Alamos National Laboratory (LANL). Individual target inventories will typically range from $2-5 \mathrm{Ci}$ /target, but could be as high as 35-70 $\mathrm{Ci}$ (this accounts for additional tritium that might be in the target support system). Targets will be transported so that no more than $100 \mathrm{Ci}$ of tritium is in transit at any time.

Impacts from routine transportation of tritium targets would not be expected, because there would be no detectable levels of radiation outside the packages carrying the low-energy beta-emitting tritium targets.

Target fill facilities will have their own National Environmental Policy Act (NEPA) determinations and safety basis documentation. The risk and consequence evaluation of transportation to NIF is provided, based on distance traveled and a bounding scenario involving a vehicle crash.

\subsubsection{Waste Generated During NIF Operations}

\subsubsection{Low-Level, Mixed and Hazardous Waste Generation}

Estimates of waste generation are inherently less certain than other environmental estimates. The environmental goal is to eliminate all waste streams, and therefore technology will be applied to reduce the wastes to the extent practicable. Waste streams are categorized according to the chemical and radiological makeup of the waste. A small change in one or more of the characteristics can result in a change in waste category, which in turn changes the manner in which the waste is managed. Process changes may arise, which result in different waste stream characteristics. Even the hazardous waste definitions, thresholds, and regulations change over time. Given the uncertainty, a best estimate of the waste streams was made based on current information.

\section{Tritium Processing/Molecular Sieves}

The tritium processing system (TPS) operates by oxidizing gaseous tritium in a reactor and capturing the oxidized tritium on molecular sieves. Wastes from this source consist of 9 to 10 waste molecular sieve canisters per year from the TPS module, replacement of the preheater reactor every ten years, replacement of gloves on glove boxes every six months, and replacement of metal bellows pumps every ten years. Recently, an additional process was identified for bake-off of the main debris shields, which is estimated to increase the generation of TPS-related wastes 
by about $20 \%$ (from the original estimate of $0.98 \mathrm{~m}^{3} / \mathrm{yr}$ (DOE, 1996)), for a new total of about $1.18 \mathrm{~m}^{3}$. An additional waste stream of palladium catalysts, $0.003 \mathrm{~m}^{3} / \mathrm{yr}$, which is assumed to be a mixed solid waste, has also been identified.

\section{Wipe Cleaning, General Cleaning}

This category of waste results from personal protective equipment (PPE) and the waste wipes and solvents associated with manual wipe cleaning of NIF materials. Both the OAB and LTAB conduct solvent wipe cleaning as part of the general cleanroom operations. Usually, the solvent used is isopropyl alcohol, although ethyl alcohol and acetone are used at times. Most of the solvent wipe cleaning is done with an aqueous solution of isopropyl alcohol, with less than $10 \%$ alcohol concentration. As long as the wipe cleaning solution is below $24 \%$ alcohol, the used wipes are not a hazardous waste due to the alcohol. In some cases, the wipes may be laundered and recycled. Used, wet wipes from aqueous solutions above $24 \%$ will be managed as hazardous waste, or mixed waste, as appropriate.

The solvent used for wipe cleaning is reported under the BAAQMD permit (S-2121). The permit has a permit condition limit, and this limit is reflected in the air emissions section, elsewhere in this document. The amount of liquid solvent managed as waste does not contribute to air emissions. Very dilute solutions, below 50 grams per liter, are below the air permit reporting threshold. In this category, 3.3 $\mathrm{m}^{3} / \mathrm{yr}$ of solid low-level waste (LLW) has been estimated. In addition, $0.3 \mathrm{~m}^{3} / \mathrm{yr}$ of liquid LLW, $1.0 \mathrm{~m}^{3} / \mathrm{yr}$ of solid mixed waste, and $1.0 \mathrm{~m}^{3} / \mathrm{yr}$ of hazardous solid waste have been estimated.

\section{HEPA Filters /Prefilters}

There will be two High-Efficiency Particulate Air (HEPA)s and two prefilters controlling the emissions from the target chamber. There will be approximately twenty additional HEPA filters with local area control applications. A changeout schedule of at least once every ten years is required by LLNL, unless the HEPA system contains in-line sprinklers (NIF does not). The LLW waste stream for HEPA filters is estimated to be $0.23 \mathrm{~m}^{3} / \mathrm{yr}$, based on the replacement of the HEPAs and prefilters every ten years.

There are many more HEPAs in the buildings that serve to provide cleanroom air. It is assumed that these HEPAs will be contaminated with ambient air contaminants only and will not be a hazardous or low level waste. The cleanroom HEPAs are not subject to the change-out schedule discussed above, because their function is not the protection of persons or the environment.

\section{Waste Hardware}

The first-wall panels, which provide protection of the target chamber, will require periodic replacement due to wear, damage and/or chemical contamination. It is 
anticipated that the panels will be replaced once every eight years, resulting in an average estimated waste stream of $1 \mathrm{~m}^{3} / \mathrm{yr}$ of LLW.

The charge-coupled device (CCD) cameras used for target chamber diagnostics may be damaged during higher yield experiments and become a solid LLW stream. There are as many as 96 cameras used at one time, but they are small $\left(\sim 10 \mathrm{~cm}^{3}\right.$ each $)$ and therefore will not increase waste totals significantly.

Current design involves a disposable debris shield concept, which would remotely insert debris shields with a mechanical device somewhat like a CD changer. The disposable debris shields function to protect the main debris shields, would be approximately $1 \mathrm{~mm}$ thick, and would be mounted in a plastic frame and held in a cassette holding about 15 debris shields. There will be an ongoing waste stream of solid LLW from the disposable debris shields, estimated at about $19.7 \mathrm{~m}^{3} / \mathrm{yr}$. Some of the main debris shields will also be disposed of due to damage, etc., estimated at about $1.9 \mathrm{~m}^{3} / \mathrm{yr}$. The use of disposable debris shields does not eliminate the need for periodic cleaning, and some shots will not employ the disposable debris shields. The waste stream from the cleaning of the debris shields is discussed below.

Other waste hardware associated with the target chamber may be disposed of as solid mixed waste because of damage or induced radiation in the material. This waste hardware is estimated to be $0.5 \mathrm{~m}^{3} / \mathrm{yr}$.

\section{Chemical Treatment and Decontamination}

This category of waste includes the cleaning of the target chamber first-wall panels and cleaning of the main debris shields and associated hardware. Alternative cleaning methods considered have included $\mathrm{CO}_{2}$ snow cleaning, laser cleaning, ultrasonic cleaning, and chemical treatment. The current recommended method is chemical treatment, using an acidic bath for the first-wall panels and a caustic bath for the main debris shields. Both of these processes require rinsing after the chemical treatment. If an acid foam is used, it would be followed with an aqueous rinse. In both cases, the chemical treatment and rinsing will generate a liquid LLW or a mixed waste. It is assumed that waste liquid from the chemical baths will be mixed waste, and waste rinsate will be LLW. The cleaning baths will be recirculated and filtered, and the solid filters will be disposed as mixed solid waste. There is the potential that much of the acid could be recovered, concentrated, and recycled, thereby reducing the waste stream estimates shown in Table 11. However, a conservative approach was taken and no recycling was assumed.

\section{Waste Oils and Associated Equipment}

Capacitors will be filled with castor oil, and waste castor oil is usually not a hazardous waste. Under current regulations, the castor oil could be drained from a spent capacitor and recycled at an off-site facility. Also, the remaining metal capacitors could be recycled at an off-site facility to recover the metal content. 
Therefore, it is possible that this waste stream could be eliminated by recycling. There is some uncertainty, however, that the oil chemistry could change over time, or that future regulations could change and impact the management of this waste stream, or the availability of suitable recycling facilities could change. Therefore, a conservative approach was taken, and recycling was not assumed. This waste stream is estimated to be a hazardous solid of $7.5 \mathrm{~m}^{3} / \mathrm{yr}$.

Vacuum pumps are used to draw a vacuum on the target chamber. An estimate of $0.2 \mathrm{~m}^{3} / \mathrm{yr}$ of mixed liquid oil waste was used in the Preliminary Environmental Impact Statement (PEIS) for vacuum pump operations. By the time of the 1998 Pollution Prevention Plan (LLNL, 1998), it was believed that oil-free pumps could be used and that this waste stream could be eliminated.

At this time, it is anticipated that vacuum pumps will be used that have oil isolated in the pump transmission casing, so there will be no oil backstreaming. The oil must be changed periodically, as part of normal maintenance. The oil from some pumps will be close to the target chamber and will result in a mixed waste stream, due to neutron activation. The oil from the other vacuum pumps could be regulated as hazardous waste.

There is still some uncertainty about the volume of hazardous waste oil (estimates range from 0.003 to $0.4 \mathrm{~m}^{3} / \mathrm{yr}$ ). Therefore, the $0.2 \mathrm{~m}^{3}$ value from the PEIS was retained as a reasonable estimate. Waste bearings from the pumps, and other spent materials, are estimated at $0.06 \mathrm{~m}^{3} / \mathrm{yr}$ of LLW.

\section{General Chemicals.}

Activities in the OAB and LTAB are expected to generate some hazardous waste, although there are pollution prevention techniques in place to eliminate hazardous wastes. The OAB has two state of the art precision cleaners, which use a nonhazardous aqueous Brulin solution for cleaning. The wastewater from these precision cleaners is sewerable, therefore, this wastewater is included in the sewage wastewater total, elsewhere in this document. The OAB also uses steam cleaning for general cleaning of surfaces, which also results in a sewerable discharge.

There are some metal treating processes, such as passivation of steel, which may result in hazardous acidic or alkaline wastewater.

The mechanical equipment in the $\mathrm{OAB}$ and LTAB, such as cranes, hoists, and transporters require periodic maintenance. The maintenance will generate some petroleum-contaminated wastes, which may be managed as hazardous waste. Maintenance work with paints, coatings, sealants and adhesives may also contribute to hazardous wastes. This waste stream is estimated at $4.6 \mathrm{~m}^{3} / \mathrm{yr}$ for the OAB and LTAB. 
Table 11. National Ignition Facility Waste Estimates for Low-Level, Mixed, and Hazardous Wastes (Per Year of National Ignition Facility Operation).

\begin{tabular}{|c|c|c|c|c|c|c|}
\hline \multirow[b]{2}{*}{ Source of Waste } & \multicolumn{2}{|c|}{$\begin{array}{l}\text { Low-Level } \\
\text { Radioactive }\end{array}$} & \multicolumn{2}{|c|}{ Mixed } & \multicolumn{2}{|c|}{ Hazardous } \\
\hline & $\begin{array}{l}\text { Solid } \\
\left(\mathrm{m}^{3}\right)\end{array}$ & $\begin{array}{c}\text { Liquid } \\
\left(\mathrm{m}^{3}\right)\end{array}$ & $\begin{array}{c}\text { Solid } \\
\left(\mathrm{m}^{3}\right)\end{array}$ & $\begin{array}{c}\text { Liquid } \\
\left(\mathrm{m}^{3}\right)\end{array}$ & $\begin{array}{c}\text { Solid } \\
\left(\mathrm{m}^{3}\right)\end{array}$ & $\begin{array}{c}\text { Liquid } \\
\left(\mathrm{m}^{3}\right)\end{array}$ \\
\hline 1. Tritium processing & 1.2 & & 0.0030 & & & \\
\hline 2. Wipe cleaning & 3.3 & 0.3 & 1.0 & & 1.0 & \\
\hline 3. HEPA filters/Pre-filters & 0.23 & & & & & \\
\hline 4. Waste hardware & 24 & & 0.5 & & & \\
\hline 5. Chemical treatment/decon & & 1.3 & 0.3 & 4.9 & & 1.5 \\
\hline 6. Waste oils/equipment & 0.060 & & & 0.2 & 7.5 & 0.2 \\
\hline 7. General chemicals & & & & & & 4.6 \\
\hline Total/yr & 29 & 1.6 & 1.8 & 5.1 & 8.5 & 6.3 \\
\hline
\end{tabular}

\subsubsection{Non-Hazardous Waste Generation}

NIF is generating and will continue to generate waste office paper, cardboard, plastic, and other non-hazardous refuse at a rate similar to the Laboratory as a whole. There is nothing unique about the refuse generation from NIF, in terms of waste types or amounts. Therefore, this type of waste will be addressed on a site-wide basis in the EIS.

\subsection{Environmental Impacts from Accidents}

This section describes the bounding accidents for NIF. Also included are the source terms and accident release characteristics.

\subsubsection{Radiological Release}

\subsubsection{Radiological Release from the Facility}

A review of accidents potentially resulting in a radiological release from NIF was conducted (LLNL, 1996). These scenarios included:

- Operational upsets resulting in tritium release.

- Loss of target chamber vacuum.

- Waste drum fire.

- Release during decontamination operations.

- Worker contamination/exposure scenarios.

- Earthquakes and other natural phenomena. 
- External events (e.g., aircraft crash).

These scenarios have varying probabilities and consequences. They also have differing release fractions and could occur at different times after the shot. To encompass all potential radiological consequences from NIF operations, a bounding scenario resulting in the release of radionuclides to the environment has been proposed. The initiating event is a severe earthquake (beyond design basis earthquake). The proposed event considers an earthquake of frequency $10^{-4} / \mathrm{yr}(\sim 1 \mathrm{~g}$ horizontal ground acceleration) occurring at the time of a maximum theoretical yield shot. Assuming 100 high-yield shots per year, the estimated frequency of the accident is $2 \times 10^{-8} / \mathrm{yr}$ (assuming a one-minute time window for the earthquake). Inventories vulnerable to release in the target bay include activated gases in the air and beam tubes and activated material in the target chamber. Tritium sources located outside the target bay in the $\mathrm{LTAB}$ would also be vulnerable to release. These primarily include tritium in elemental form as stored targets or on the cryopumps, or tritium as oxide on the molecular sieve of the tritium processing system.

The target building has been shown to withstand a severe earthquake $(\mathrm{Ng}, 1995)$, but other areas and components have not been analyzed beyond their design basis. The beam tubes leading from the switchyard into the target chamber are assumed to fail in the proposed earthquake. The switchyards may sustain the earthquake but are conservatively assumed to collapse. Components of the tritium processing system may be compromised, and the area could be flooded by water released from failed water supply piping. Further, natural gas piping is found in areas of the LTAB outside the target bay. Thus, localized fires outside the target bay could be expected under these extreme conditions.

For inventories in the target bay, a pathway out to the environment is created through the beam tube penetrations in the target bay walls. Airborne activity in the target bay would be swept out to the environment by wind blowing through this volume. The wind is assumed to blow in through the penetrations on one side of the target bay, and out through the penetrations on the opposite side. Tritium sources would be released directly to the environment, as they are not located in the target bay. Dispersion in the environment will take place as the material is transported downwind.

\section{Source Terms}

Radioactive inventories vulnerable to release include: (1) activated gases; (2) activated particulate in the target chamber; and (3) tritium.

\section{(1) Activated Gases:}

If the earthquake were to occur immediately after a high-yield shot, ${ }^{5}$ air activation products in the target bay atmosphere and beam tubes would be available for release.

\footnotetext{
5 The accident is assumed to occur after the last maximum-yield shot of the year and is assumed to achieve the maximum credible yield of $45 \mathrm{MJ}$.
} 
Inventories of activated gases created in the target bay atmosphere as a result of a maximum yield shot are provided in Table 4 .

As noted previously, a direct pathway to the environment is assumed to be created by the seismic event for the release of activated air in the target bay. As the wind blows from one collapsed switchyard through the beam tube penetrations on one side of the target bay, through the target bay, and then out through the beam tube penetrations and collapsed switchyard on the opposite side, the activated air will be forced out. No mitigation is assumed.

\section{(2) Activated Particulate}

As described previously, it is expected that a small quantity of activated debris will be created in the target chamber. Conservatively, for the purpose of this analysis, it is assumed that all of this solid debris will exist as fine particulate.

The particulate will accumulate in the target chamber until a scheduled cleanup. It is conservatively assumed here that the material accumulates in the chamber for one year. The dispersible target chamber inventories (i.e., the inventory in the form of particulate) subsequent to the last yield shot of the year (assumed to be at the maximum theoretical yield of $45 \mathrm{MJ}$ ) are provided in Table 4.

Collapse of the beam tubes and failure of debris shields, diagnostic windows, etc., will expose many penetrations to the chamber. This will allow rapid air ingress to the target chamber. The inflow of air will disturb any settled particulate, causing it to become airborne within the target chamber. A conservative airborne release fraction of $10^{-3}$ for solid particulate is assumed here. Presently there are not enough data to indicate whether the particulate is loosely or tightly adherant to the target chamber surface. With rapid air ingress that is assumed to occur in the event, some of the particulate on the surface could become airborne due to resuspension mechanisms. Resuspension occurs as a result of mechanical disturbances as well as by wind. In what follows, a simple method will be used to estimate the airborne release fraction (ARF) based on the resuspension data. The ARF is used to estimate the release of material in particulate form to the environment.

The resuspension factor is defined as (Randerson, 1984, Chapter 12):

$\mathrm{RF}=$ airborne concentration / surface concentration

Applying the definition of RF to the target chamber, one obtains:

$$
\begin{aligned}
\mathrm{RF} & =\left(\text { airborne particulate } / 4 \pi / 3^{*} \mathrm{R}^{3}\right) /\left(\text { particulate on surface } / 4 \pi^{*} \mathrm{R}^{2}\right) \\
& =(3 / \mathrm{R})^{*} \text { (airborne particulate/ particulate on surface) } \\
& =(3 / \mathrm{R})^{*} \mathrm{ARF}
\end{aligned}
$$

where $R$ is the radius of the target chamber. Thus, 
$\mathrm{ARF}=(\mathrm{R} / 3)^{*} \mathrm{RF}$

The resuspension factor, $\mathrm{RF}$, is not precisely measured, and the data span a large range. The value ranges from $10^{-9}$ to $10^{-4} \mathrm{~m}^{-1}$ for wind resuspension and from $10^{-7}$ to $10^{-3}$ $\mathrm{m}^{-1}$ for mechanical disturbance (Randerson, 1984). During the beyond design basis earthquake, the presumed cracking and partial failure of the target chamber and target bay will produce various mechanical disturbances, and air flow inside the target chamber and result in resuspension. Using the target chamber radius of $5 \mathrm{~m}$, the ARF ranges from $10^{-9}$ to $10^{-3}$. In this evaluation, the conservative value of $10^{-3}$ is used for the ARF. Note that according to DOE-STD-1027 (DOE, 1997), an average ARF of $10^{-3}$ is used generally for solids, powders, and liquids for various accidents in facility categorization.

The dispersible activated material will be swept from the chamber by the wind blowing through the target bay. It will then leave the target bay with the other airborne activity as described previously. No mitigation is assumed. Some deposition of the particulate would occur within the target chamber and target bay. Including in-facility deposition would reduce the quantity of radioactive material reaching the environment. This has not been considered at this time. Thus, a conservative source term has been estimated.

\section{(3) Tritium}

Tritium will arrive at the facility in targets containing up to $35 \mathrm{Ci}$ (an additional $35 \mathrm{Ci}$ may be in the associated support structure, for a total maximum target assembly inventory of $70 \mathrm{Ci}$ ). It is planned to have no more than $100 \mathrm{Ci}$ of tritium in the facility in the form of targets and associated support structure. Individual targets will be placed in the target chamber for shots. Unburned tritium will be exhausted and retained in the tritium processing system. The inventory in the collection system can be controlled and maintained such that the maximum facility in-process inventory would not exceed $500 \mathrm{Ci}$. Active inventory control and periodic removal of the molecular sieve and transfer to shipping containers for disposal or recovery off-site will accomplish this.

The seismic event could lead to the release of any tritium contained in targets. Release could occur as a result of direct crushing of the targets or failure of the cryogenic support system leading to pressurization and failure of the capsule. This tritium would be released from the targets in the elemental form. However, there may be small quantities of flammables (solvents) in the area. Thus, there exists the small possibility of a fire. As noted below, it is presumed that the fire mitigation system would be unavailable during this event. For the purpose of this severe accident analysis, the probability of the fire occurring and continuing for some time, is taken to be 1.0. Thus, any tritium released from targets is conservatively assumed to become oxidized and to be released as more hazardous tritiated water. Because the targets would be stored in an area that could be severely damaged by this earthquake, the tritium released from the targets would directly enter the environment. 
During the hypothesized seismic event, it is possible that there would be damage to components of the tritium processing system. These are designed to survive the design basis earthquake. Their behavior in more severe earthquakes is not known, and thus, these components are assumed to fail (i.e., the molecular sieve would be directly exposed to the atmosphere). As noted above, under the extreme conditions of this accident, a fire could occur in the vicinity of the tritium processing system. This would provide an energy source for the release of the tritium from the molecular sieve directly into the atmosphere. It is also possible that water piping in the area would fail leading to flooding. Water sources might include domestic water, low conductivity water $(\mathrm{LCW})$, and fire protection water. It is much more likely that the domestic and LCW supplies would fail when compared to the fire sprinkler system. The sprinkler system has been designed to NFPA standards and would survive the design basis earthquake. Because the behavior of the sprinkler system under more severe seismic loads is not known, failure is postulated. If this is the case, any fire in the area would be unmitigated. If the area is flooded, an alternate release pathway is provided. Flooding would provide the opportunity for exchange with the material absorbed on the molecular sieve, and would result in tritium contamination of the water pool. ${ }^{6}$ Subsequent evaporation from the pool would release the tritium to the environment via the airborne pathway, although at a much slower rate than the fire release mechanism. In either case, the tritium would directly enter the environment, as the tritium processing area is located outside of the target bay in a location that would likely be severely damaged by the earthquake.

The total tritium source term would be $500 \mathrm{Ci}$. The most conservative source term would result from a fire in the area, because the release would occur more quickly and all of the tritium would be released in the more hazardous oxide form. The entire tritium inventory could be released over a fairly short time period ( 3 minutes would be a conservative estimate to release all of the tritium from the molecular sieve).

For this very severe scenario, $100 \%$ of the tritium inventory is conservatively assumed to be released from the decontamination area. The activation product inventories and activated gases provided previously in Table 4 are also assumed to be released, with a release fraction of $10^{-3}$ for particulate and 1.0 for gases. The inventories that could be released under severe accident conditions are summarized in Table 12.

\footnotetext{
6 Note that this release scenario requires that the water supplies fail in the most undesirable way, i.e., failure occurs in the worst location for tritium release, rather than, for example, at some location outside of the building.
} 
Table 12. NIF LTAB Estimated Maximum Radionuclide Inventories Released under Severe Accident Conditions.

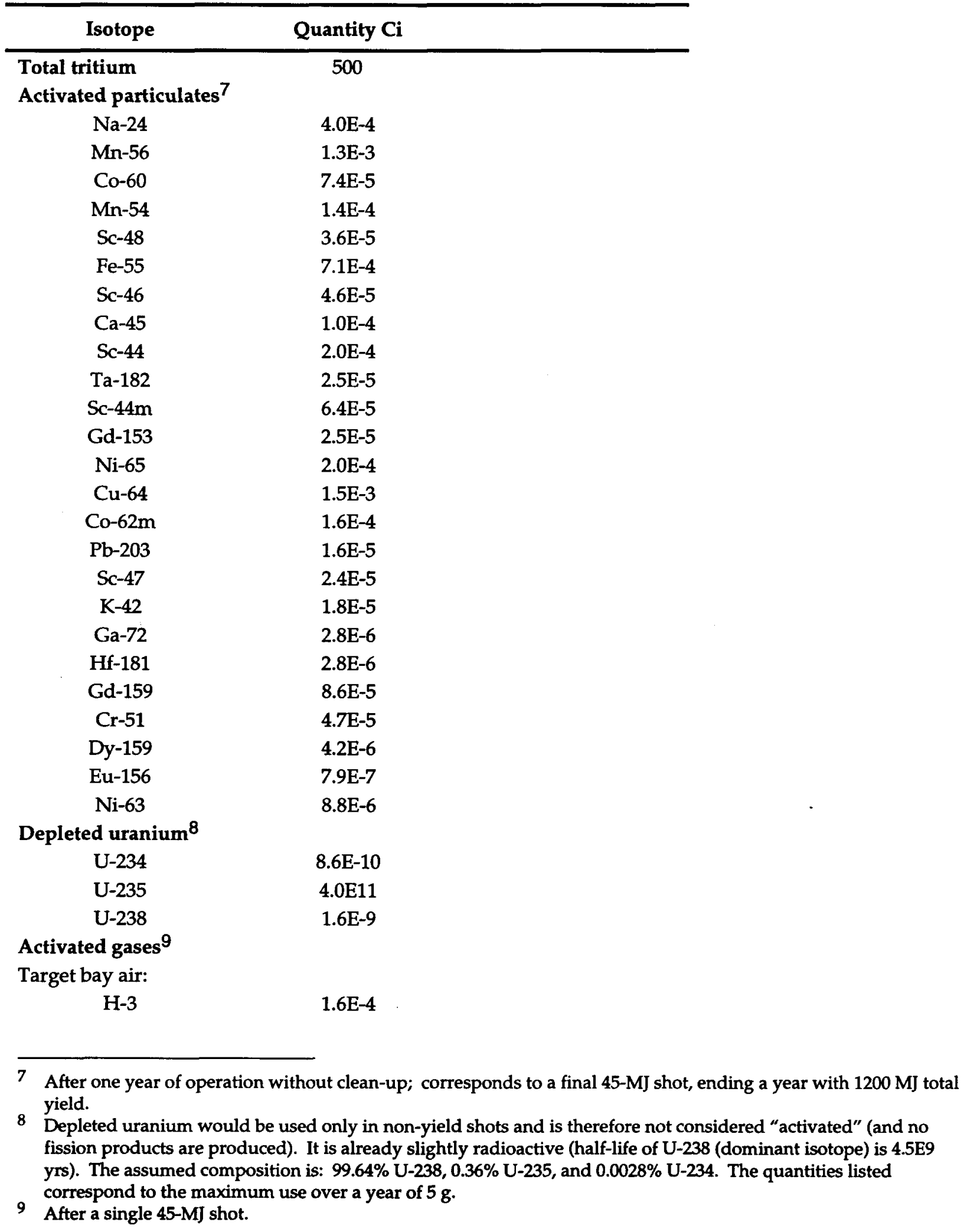




$\begin{array}{cc}\mathrm{N}-13 & 1.9 \mathrm{E} 1 \\ \mathrm{~N}-16 & 3.2 \mathrm{E} 3 \\ \mathrm{~S}-37 & 4.2 \mathrm{E}-1 \\ \mathrm{Cl}-40 & 2.4 \\ \mathrm{Ar}-41 & 1.6 \\ \mathrm{C}-14 & 4.9 \mathrm{E}-5\end{array}$

Argon in beam tubes:

$\mathrm{H}-3$

4.7E-6

S-35

2.3E-5

Ar-37

$4.1 \mathrm{E}-4$

Ar-39

$1.7 \mathrm{E}-3$

Ar-41

\subsubsection{Radiological Release during Transportation}

Radiological impacts associated with the transportation of tritium targets would result from a release of tritium into the environment following a transportation accident. Since tritium is a pure beta emitter with no associated gamma radiation, radiological risks associated with routine (incident-free) transportation operations are negligible.

The potential radiological impacts of transporting tritium targets should be calculated for truck and air travel. Trucks can be assumed to transport the tritium targets from the off-site manufacturing sites to the nearest major airport, while cargo aircraft can be assumed to transport the targets to a local airport. After arriving at the airport, the targets would be transferred to a truck for shipment to NIF at LLNL. Onsite transportation of targets from the LLNL target source (Superblock) would occur by truck. The scenario presenting the most significant consequences is likely to be a vehicular crash involving a fire.

\section{Source Term}

NIF targets may come from as far away as LANL, or be produced locally at LLNL (Superblock). Individual target inventories will typically range from $2-5 \mathrm{Ci} /$ target, but could be as high as 35-70 $\mathrm{Ci}$ (accounting for additional tritium that might be in the target support system). Targets will be transported so that no more than $100 \mathrm{Ci}$ of tritium is in transit at any time. For assessment purposes, it should be assumed that the entire tritium cargo is released to the environment in oxide form.

\section{Consequences}

The consequences should be assessed for a general population located in an urban population density zone. Maximally exposed individuals should be exposed and unshielded as the plume passes. Radiological consequences should be assessed using 
worst-case weather conditions for both the collective population and the maximally exposed individual.

\subsubsection{Hazardous Material Release}

As noted previously, two types of materials involved in the NIF operations contribute to the non-radiological hazard. They are:

- Hazardous chemicals. These chemicals would be used at NIF for a variety of purposes, including cleaning, decontamination processes, and in support of electrical equipment operation. Table 2 lists the maximum quantities of these materials expected to be in use at NIF.

- Material in particulate form. During a shot, the target shell, hohlraum, and target-positioning apparatus would be vaporized and would condense as fine particulate inside the target chamber. In addition, some ablation of the firstwall material, debris shields, and diagnostics are expected during a shot and would also produce material in particulate form inside the target chamber. Table 3 lists the bounding annually produced quantity of material in particulate form. Note that many materials are not hazardous in solid form but may become hazardous in fine particulate, respirable form.

A review of accidents potentially resulting in a release of non-radiological material from NIF was conducted (LLNL, 1996). These scenarios included:

- Spills, such as solvents or decontamination solutions.

- Failure of electrical equipment.

- Waste drum fire.

- Loss of target chamber vacuum/particulate release.

- Earthquake or other natural phenomenon.

- External event (e.g., aircraft crash).

These scenarios have varying probabilities and consequences. They also have differing release fractions. To encompass all potential consequences from NIF operations, bounding scenarios have been selected. These are discussed below.

\subsubsection{Material Spill}

Solvents would be used for miscellaneous cleaning activities throughout the LTAB and $\mathrm{OAB}$; acidic and caustic solutions would also be used for various decontamination operations in the decontamination area of the Diagnostics Building. An anticipated 
scenario that might occur is a spill of solvent or decontamination solution onto the ground outside the facility, possibly caused by a forklift during handling or movement.

Projected inventories of solvents and decontamination solutions to be used in the LTAB or OAB are provided in Table. 2 . The chemicals evaluated were selected on the basis of amount of material at risk, exposure criteria, and volatility. That is, chemicals without inventory thresholds that are expected to be present in relatively small quantities, with low volatility, and those with relatively high exposure criteria were not considered further. Many of the solvents and decontamination chemicals listed in Table 2 could be eliminated from further analysis on this basis. In the end, one solvent (acetone) and one decontamination material (nitric acid) should be examined to determine potential consequences.

Table 13. Summary of More Significant Solvent and Decontamination Solution Inventories.

\begin{tabular}{lc}
\hline \multicolumn{1}{c}{ Solvent } & Inventory (L) \\
\hline Acetone & 210 \\
Nitric Acid Solution $(70 \%)$ & $400 \mathrm{~L}$ \\
\hline
\end{tabular}

\section{Source Terms}

If a spill occurs, the material is assumed to form a puddle on the ground and is subsequently allowed to evaporate. No mitigation is assumed. A minimum puddle depth of $1 \mathrm{~cm}$ should be assumed, and the ambient temperature should be assumed to be $95^{\circ} \mathrm{F}$. The evaporated material is dispersed to the environment. Based on the quantity of material available to spill (see summary in Table 13), material properties, and hazard level, the most severe spill can be determined. This will bound the other spill scenarios.

\section{Consequences}

The downwind concentrations should be calculated at $100 \mathrm{~m}$ for the solvent and $365 \mathrm{~m}$ for the decontamination solution (nitric acid). These are the distance from the $\mathrm{OAB}$ loading dock to the site boundary (a potential location for any of the solvents) and the distance from the decontamination area to the site boundary (the location of the nitric acid solution).

\subsubsection{Mercury Release from Ignitrons}

Electrical equipment in NIF may contain castor oil (capacitors), mercury (PAM PCUs) or ethylene glycol (PAM coolant). Mercury is significantly more hazardous than the other materials. Therefore, a scenario involving mercury should be examined. 
PCUs are used in support of the PAMs located in the laser bays. There are a total of 48 PCUs. Each PCU has four ignitron switches, and each ignitron switch contains $0.018 \mathrm{~L}(245 \mathrm{~g})$ of mercury. A scenario involving a single PCU (four switches) has been postulated to bound the mercury release from the facility. The initiator for this scenario is an explosive failure of an ignitron switch (Cummings, 1991).

\section{Source Terms}

The explosive release is expected to create a spray of liquid droplets and a small quantity of vapor. Though the PCUs are enclosed in a 6-mm-thick steel box, the explosion is postulated to produce enough energy to cause the failure of this enclosure. The liquid droplets would deposit in the immediate vicinity of the failed switch and form a puddle, while the vapor would remain airborne. No mitigation is assumed. To evaluate the impact of this event, two source terms are estimated:

- The airborne mercury is estimated using a release fraction of 0.01 based on DOESTD-1027 (DOE, 1997); this corresponds to a total of $9.8 \mathrm{~g}$ of airborne mercury.

- The puddle from the four failed PCU switches consists of approximately $0.98 \mathrm{~kg}$ $(0.072 \mathrm{~L})$ of mercury. Evaporation of the mercury should be determined for a puddle depth of $1 \mathrm{~cm}$, at an ambient temperature of $68^{\circ} \mathrm{F}$. The vapor will then be released to the environment through the laser bay HVAC discharge point.

\section{Consequences}

The release of mercury to the environment would take place over a relatively long period of time, since the discharge rate from the laser bay is about $6 \mathrm{~m}^{3} / \mathrm{s}(0.5$ air change per hour). The location of the Laser Bay discharge point closest to the public is $280 \mathrm{~m}$ from the site boundary and $21 \mathrm{~m}$ above ground.

\subsubsection{Particulate Release}

Several accident scenarios could result in the release of material in particulate form. They are a waste drum fire, a target chamber vacuum window failure, and a beyond design-basis earthquake.

The beyond-design-basis earthquake is identical to the one described in the radiological release, Section 2.3.1.1. The airborne release fraction (ARF) for this scenario is $1 \times 10-3$ (see discussion in Section 2.3.1.1) and the respirable fraction is 1 . Note that the ARF is defined as the ratio of the airborne material to the material at risk, and the respirable fraction is defined as the fraction of airborne material that is respirable (in the respirable range (i.e., the aerodynamic equivalent diameter is less than $10 \mathrm{~mm}$ )). This scenario will be used as a bounding case to estimate the amount of material in particulate form released to the environment. The waste drum scenario and vacuum window failure scenario are bounded by the earthquake scenario because the source terms and associated release fractions are bounded by the earthquake. 


\section{Source Terms}

An airborne release fraction of $10^{-3}$ can be applied to the material in particulate form listed in Table 3. This gives the quantity of material that becomes airborne, as summarized in Table 14. No mitigation is assumed.

Table 14. Summary of Released Particulate Inventories.

\begin{tabular}{|c|c|}
\hline Material & Quantity Released (g) \\
\hline $\mathrm{Al}$ & $2.1 \mathrm{E} 0$ \\
\hline $\mathrm{Au}$ & $4.0 \mathrm{E}-2$ \\
\hline $\mathrm{Be}$ & $1.6 \mathrm{E}-3$ \\
\hline $\mathrm{Cu}$ & $1.7 \mathrm{E}-1$ \\
\hline Dy & $2.1 E-3$ \\
\hline $\mathrm{Fe}$ & $2.6 \mathrm{E}-1$ \\
\hline Gd & 2.0E-2 \\
\hline $\mathrm{Ge}$ & $2.0 \mathrm{E}-2$ \\
\hline $\mathrm{Pb}$ & 3.0E-2 \\
\hline Sc & $7.0 \mathrm{E}-3$ \\
\hline $\mathrm{Si}$ & $5.0 \mathrm{E}-1$ \\
\hline Ta & 2.9E-2 \\
\hline $\mathrm{Ti}$ & $1.0 \mathrm{E}-2$ \\
\hline $\mathbf{U}$ & $5.0 \mathrm{E}-3$ \\
\hline B4C & 1.1E0 \\
\hline
\end{tabular}

\section{Consequences}

Consequences should be assessed at $350 \mathrm{~m}$ from the facility (site boundary) since the source term would be derived from the target bay.

\subsubsection{Aircraft Crash}

The probability of a light aircraft crash impacting the NIF LTAB has been found to be a credible event (frequency of occurrence approximately $1.6 \times 10^{-4} / \mathrm{yr}$ ), based on a study performed for the LTAB (Kimura, 1996). Specific areas of concern from a release of material standpoint are the tritium handling and processing/ decontamination areas and the laser bays. If the aircraft crashed into other areas of the LTAB, there would be facility damage, but the accident would not result in the release of hazardous or radioactive material.

The NIF target bay is constructed of thick, reinforced concrete. The primary purpose of this construction is radiological shielding; however, as an additional benefit, the construction also makes the facility essentially impervious to impact by light aircraft. Should an aircraft crash into the target bay, the chief hazard would be to the occupants of the aircraft and any on-site personnel in the way of falling plane wreckage and burning aviation fuel. The thickness of the reinforced concrete walls and roof are 
such that they will withstand the impact of a direct hit from a small aircraft. The switchyard is also constructed of reinforced concrete, a minimum of $0.61 \mathrm{~m}$ thick. This area is also impervious to a light aircraft.

The Diagnostics Building is a metal frame building with steel siding. An aircraft crashing into this area could potentially cause substantial damage. There may be an inventory of tritium targets in the building (up to $100 \mathrm{Ci}$ ), which could be released if located on the upper floors. The consequences of this release are bounded by the tritium release event previously analyzed (see Section 2.3.1.1). The tritium processing/ decontamination area is located in the basement of the diagnostics building. This area, however, is invulnerable to an aircraft crash. Any airplane would first have to penetrate an exterior wall of the diagnostics building and then the ceiling of the tritium processing/ decontamination area, which is a concrete slab on the order of $15 \mathrm{~cm}$ thick. The kinetic energy of the aircraft would be substantially diminished by the initial impact, such that the tritium processing/decontamination area is expected to be unaffected. Any release of radioactivity from the facility would be bounded by events already analyzed.

The roof of the two outer capacitor bays is steel deck with concrete fill (approximately $10 \mathrm{~cm}$ thick). The outer walls are constructed of steel beams and girders with metal siding for the walls. This area is vulnerable to a small aircraft crash. However, there is no radioactive material or any significant hazardous material that could be released from these areas in the event of a crash. The PCUs in this location previously contained quantities of mercury that would have been releasable in this event. However, the mercury-containing ignitron switches have been replaced with spark gap switches, which do not contain any hazardous material.

The roof of the laser bays and mechanical equipment area is steel deck with concrete fill (approximately $10 \mathrm{~cm}$ thick), and the exterior walls are metal siding. These areas would be vulnerable to damage if a small aircraft impacted the area. There is a small possibility that an aircraft could impact PAM PCUs (different than the main PCUs located in the Capacitor Bays) and result in the release of mercury from the ignition switches.

The PCUs are used in support of the PAMs, which are part of the preamplifier system that provides laser energy gain to the low-level input pulse. The PCUs are steelframed boxes with 0.25 -in. steel plate siding. The two laser bays each house 24 PCUs, and each PCU has four mercury-containing ignitron switches for about 0.072-L mercury total per PCU.

Only a small part of each laser bay's walls are actually exterior walls. Most of the laser bay walls are interior walls, adjoining the capacitor bays. Capacitor Bays 1 and 4 act as buffers between most of the laser bays and the exterior. A small aircraft crashing into an outer capacitor bay is not expected to reach a laser bay. For an aircraft to reach a PAM PCU, a crash must occur either through the section of exposed laser bay wall $(\sim 150 \mathrm{ft}$ for each laser bay) or through the laser bay roof. The likelihood of penetration 
through the sidewalls of the laser bays and impacting a PAM is extremely unlikely for a combination of reasons. The first is that the direction of the penetrating aircraft would have to be perpendicular to the normal flight path taken by aircraft in this area on approach to the Livermore Airport. Secondly, in addition to the direct protection the external capacitor bays provide for the laser bay walls, they protrude and also serve to "shadow" or hide the exposed portion of the laser bay walls (considering the normal direction of travel of the aircraft) further reducing the available aircraft impact angle. Lastly, the $1.6 \times 10^{-4} / \mathrm{yr}$ accident frequency pertains to the entire LTAB area. When the susceptible area (surface area of all 48 PCUs) is ratioed to the LTAB area, the accident probability is substantially reduced.

The roof of the laser bay is not expected to provide much protection against a crashing airplane, but many obstacles would still stand between the plane and a PCU. Just below the roof is a layer of steel frames in the vertical, horizontal, and transverse directions. At this point, the main body of the light aircraft, to include the fuel-filled wings, would be sheared off. Because most of the mass of the light airplane is associated with the engine, it is this component of the plane that would cause the most damage. The engine would then have to pass through a series of barriers, including the beam transport system, a laser structural support system, comprising steel piping, steel reinforced concrete members, structural steel members, and concrete-steel composite members, before reaching a PCU. The aircraft engine must then penetrate the 0.25 -in. steel panels of the PCU before damaging the set of ignitron switches. Consequently, a PCU located within a laser bay is not expected to be affected by an aircraft crash as the above-enumerated barriers would provide substantial protection.

\section{Source Term}

In the event such a remote incident would occur, only one PCU containing four switches $(0.072 \mathrm{~L}, 0.98 \mathrm{~kg}$ of mercury) would be expected to be damaged. As there is a separation between the fuel in the wings and the aircraft engine upon impact with the roof, the spilled mercury would not be expected to be involved in a fire. The temperature of the mercury pool is taken as $90^{\circ} \mathrm{C}$, to account for possible heat transfer from warm engine parts. This scenario would then result in the evaporation of spilled mercury.

\section{Consequences}

Consequences should be evaluated at a distance of $270 \mathrm{~m}$ from the site boundary. This is the approximate distance from the PAMs in the laser bay to the site boundary.

\subsubsection{Transportation Accident}

Other non-radiological impacts of transportation, such as pollution and vehicular accidents should be evaluated. 


\section{Reduced Action Alternative}

This section describes the changes in environmental impacts that would be associated with the reduced action alternative, with respect to the No Action case. The reduced action alternative is defined as operating the facility at an annual yield of 800 MJ. Only changes are discussed.

\subsection{NIF Operation Under the Reduced Action Alternative}

The Reduced Action Alternative achieves the same individual shot yield of $20 \mathrm{MJ}$ (45 MJ maximum theoretical yield) as the No Action Alternative. However, in this alternative, the annual yield is reduced to $800 \mathrm{MJ} / \mathrm{yr}$ and the tritium throughput is reduced to $1,500 \mathrm{Ci} / \mathrm{yr}$. These changes reduce specific environmental impacts such as low-level waste generation. This reduced annual yield does not meet the full NIF Stockpile Stewardship mission. However, by maintaining the full operations and support facilities staff, the facility is in complete operational readiness, and the annual yield could be raised to the No and Proposed Action level of 1,200 MJ/yr and the tritium throughput to $1,750 \mathrm{Ci} / \mathrm{yr}$ by NNSA/DOE at any time. In the Reduced Action operation, the capability to perform tests with either indirect drive or direct drive (after reconfiguration of laser beams and final optics assemblies) would exist. Table 15 below summarizes the operational parameters for the Reduced Action Alternative.

Table 15. Operating Parameters for Reduced Action Alternative.

\begin{tabular}{ll}
\hline \multicolumn{1}{c}{ Operating Parameter } & \multicolumn{1}{c}{ Value } \\
\hline Maximum shot yield & $20 \mathrm{MJ}$ maximum planned; 45 MJ maximum \\
& theoretical \\
Total yield & $800 \mathrm{MJ} / \mathrm{yr}$ \\
Tritium throughput & $1,500 \mathrm{Ci} / \mathrm{yr}$ \\
Maximum tritium inventory & $500 \mathrm{Ci}$ \\
Tritium effluent & $30 \mathrm{Ci} / \mathrm{yr}$ \\
\hline
\end{tabular}

\subsubsection{Radioactive Materials Use/Production}

The facility tritium throughput required for the reduced action alternative would be reduced to approximately $1,500 \mathrm{Ci} / \mathrm{yr}$. The maximum in-process facility inventory $(500 \mathrm{Ci})$ and the routine tritium release $(30 \mathrm{Ci} / \mathrm{yr})$ would be unchanged.

During DT fusion shots, the NIF would generate neutron activation products in the target bay air. The total annual inventories of radioactive gases produced scales directly with annual yield. For $800 \mathrm{MJ} / \mathrm{yr}$, the inventories produced are provided in Table 16. 
Table 16. Neutron-Induced Radioactivity Produced in Target Bay Air, Based on 800-MJ/yr Fusion Yield.

\begin{tabular}{ccc}
\hline $\begin{array}{c}\text { Nuclide } \\
\text { produced }\end{array}$ & Nuclide half-life & $\begin{array}{c}\text { Production } \\
\text { (Ci/y) }\end{array}$ \\
\hline H 3 & $12.33 \mathrm{y}$ & $2.88 \mathrm{E}-03$ \\
C 14 & $5730 \mathrm{y}$ & $8.67 \mathrm{E}-04$ \\
N 13 & $9.99 \mathrm{~min}$ & $3.41 \mathrm{E}+02$ \\
N 16 & $7.13 \mathrm{~s}$ & $5.61 \mathrm{E}+04$ \\
S 37 & $5.06 \mathrm{~min}$ & $7.40 \mathrm{E}+0$ \\
Cl 40 & $1.42 \mathrm{~min}$ & $4.27 \mathrm{E}+01$ \\
Ar 41 & $1.83 \mathrm{~h}$ & $2.79 \mathrm{E}+01$ \\
\hline
\end{tabular}

\subsection{Environmental Impacts during Routine Operations}

\subsubsection{Radiological Emissions and Worker Exposures during Routine Operations}

During routine NIF operations, experiments will result in normal atmospheric releases of small quantities of tritium and some radionuclides produced from activation of gases in the air. Annual emissions of activated gases based on 800-MJ/yr of yield are provided in Table 17. As with the No Action Alternative, it is also expected that up to $30 \mathrm{Ci} / \mathrm{yr}$ of tritium will be released during maintenance activities, when equipment is opened up or brought up to air.

Table 17. Routine Radiological Releases from NIF for the Reduced Action.

\begin{tabular}{cccc}
\hline $\begin{array}{c}\text { Nuclide } \\
\text { produced }\end{array}$ & Nuclide half-life & $\begin{array}{c}\text { Production } \\
(\mathbf{C i} / \mathbf{y})\end{array}$ & $\begin{array}{c}\text { Emissions } \\
(\mathrm{Ci} / \mathrm{y})\end{array}$ \\
\hline Activated Air: & & & \\
H 3 & $12.33 \mathrm{y}$ & $2.88 \mathrm{E}-03$ & $2.88 \mathrm{E}-03$ \\
$\mathrm{C} 14$ & $5730 \mathrm{y}$ & $8.67 \mathrm{E}-04$ & $8.67 \mathrm{E}-04$ \\
$\mathrm{~N} 13$ & $9.99 \mathrm{~min}$ & $3.41 \mathrm{E}+02$ & $4.52 \mathrm{E}+1$ \\
$\mathrm{~N} 16$ & $7.13 \mathrm{~s}$ & $5.61 \mathrm{E}+04$ & $1.02 \mathrm{E}+2$ \\
$\mathrm{~S} \mathrm{37}$ & $5.06 \mathrm{~min}$ & $7.40 \mathrm{E}+0$ & $5.29 \mathrm{E}-1$ \\
$\mathrm{Cl} 40$ & $1.42 \mathrm{~min}$ & $4.27 \mathrm{E}+01$ & $8.60 \mathrm{E}-1$ \\
Ar 41 & $1.83 \mathrm{~h}$ & $2.79 \mathrm{E}+01$ & $1.75 \mathrm{E}+1$ \\
Tritium (releases & & & 30 \\
during & & & \\
maintenance) & & & \\
\hline
\end{tabular}

As noted previously, personnel would be exposed to two sources of prompt radiation during NIF yield operations: direct radiation and skyshine. These exposure pathways would be reduced by two-thirds for the 800-MJ/yr Reduced Option case, compared to the 1200-MJ/yr No Action case. For the Reduced Option, the skyshine 
dose at the nearest site boundary ( $350 \mathrm{~m}$ due east from the target bay) would be less than $0.13 \mathrm{mrem} / \mathrm{yr}$ for all possible target illumination configurations. The dose at the site boundary would be dominated by neutron skyshine (direct dose is small by comparison).

Personnel within the NIF or "passing by" would also receive a prompt dose. Operations personnel, located in the Main Control Room, would receive a prompt dose of about $3 \mathrm{mrem} / \mathrm{yr}$. Those in the Diagnostics Building would receive about $2 \mathrm{mrem} / \mathrm{yr}$, and those in the OAB would receive $0.7 \mathrm{mrem} / \mathrm{yr}$. These prompt doses are based upon a 40-hour work week. Finally, someone moving past the facility would receive a prompt dose of approximately $0.7 \mathrm{mrem} / \mathrm{yr}$ (assumes an occupancy of $1 / 16$ for walkways and roads as recommended by the National Council on Radiation Protection (NCRP, 1977)).

During high-yield operations, tasks that must be performed within the NIF target bay or that involve handling of materials that have been inside the target bay during high-yield experiments will result in some level of radiation dose. At short times after a shot, dose rates within the target bay are dominated by the yield of the most recent shot. Individual shot yields are not expected to change for the Reduced Option. However, with the reduced annual yield, there exists the potential to reduce worker dose. This derives primarily from the reduced total number of shots, which provides the opportunity for increased stay-out time after shots. This would be leveraged to the maximum extent feasible to reduce worker doses for the Reduced Option. In any case, the worker dose would be maintained less than 10 person-rem/yr.

\subsubsection{Transport of Targets}

Tritium inventories within individual targets would not be expected to change for the reduced option. However, the frequency of delivering such targets would be reduced by approximately $14 \%$, based on the expected tritium throughputs for each case.

\subsubsection{Waste Generated during NIF Operations}

Many of the waste streams would be unchanged for the Reduced Option, as they are not directly related to annual yield. Other waste streams, such as target chamber hardware or decontamination wastes, would be expected to change in proportion to the annual yield. A summary of the waste stream estimates for the Reduced Option is provided in Table 18. 
Table 18. National Ignition Facility Waste Estimates for Low-Level, Mixed, and Hazardous Wastes (Per Year) for Reduced Option.

\begin{tabular}{|c|c|c|c|c|c|c|}
\hline \multirow[b]{2}{*}{ Source of Waste } & \multicolumn{2}{|c|}{ Low-Level } & \multicolumn{2}{|c|}{ Mixed } & \multicolumn{2}{|c|}{ Hazardous } \\
\hline & $\begin{array}{c}\text { Solid } \\
\left(\mathrm{m}^{3}\right)\end{array}$ & $\begin{array}{c}\text { Liquid } \\
\left(\mathrm{m}^{3}\right)\end{array}$ & $\begin{array}{l}\text { Solid } \\
\left(\mathrm{m}^{3}\right)\end{array}$ & $\begin{array}{c}\text { Liquid } \\
\left(\mathrm{m}^{3}\right)\end{array}$ & $\begin{array}{c}\text { Solid } \\
\left(\mathrm{m}^{3}\right)\end{array}$ & $\begin{array}{c}\text { Liquid } \\
\left(\mathrm{m}^{3}\right)\end{array}$ \\
\hline 1. Tritium processing & 1.2 & & 0.0030 & & & \\
\hline 2. Wipe cleaning & 3.3 & 0.30 & 1.0 & & 1.0 & \\
\hline 3. HEPA filters/pre-filters & 0.23 & & & & & \\
\hline 4. Waste hardware & 15 & & 0.33 & & & \\
\hline 5. Chemical treatment/decon & & 0.65 & 0.20 & 3.3 & & 1.5 \\
\hline 6. Waste oils/equipment & 0.06 & & & 0.2 & 7.5 & 0.2 \\
\hline 7. General chemicals & & & & & & 4.6 \\
\hline Total/yr & 20 & 0.95 & 1.6 & 3.5 & 8.5 & 6.3 \\
\hline Change from No Action & -9 & -0.65 & -0.2 & -1.6 & - & - \\
\hline
\end{tabular}




\section{Proposed Action}

\subsection{NIF Operation Under the Proposed Action Alternative}

The Proposed Action Alternative adds to the operating parameters of the No Action Alternative proposed experiments with the following materials: plutonium, other fissile materials, fissionable materials other than depleted uranium, and lithium hydride, which were addressed in the 1998 Memorandum and Order (Sporkin, 1998). The other experiments addressed in that Memorandum and Order and a Neutron Multiplying Assembly (NEUMA) are not in the NNSA/DOE proposal (DOE, 2000) and will not be evaluated. The basic operating parameters for the Proposed Action Alternative would be as summarized in Table 19.

Table 19. Operating Parameters for the Proposed Action Alternative.

\begin{tabular}{ll}
\hline \multicolumn{1}{c}{ Operating Parameter } & \multicolumn{1}{c}{ Value } \\
\hline Maximum shot yield & $20 \mathrm{MJ}$ maximum planned; 45 MJ maximum \\
& theoretical \\
Total yield & $1200 \mathrm{MJ} / \mathrm{yr}$ \\
Tritium Throughput & $1,750 \mathrm{Ci} / \mathrm{yr}$ \\
Maximum Tritium Inventory & $500 \mathrm{Ci}$ \\
Tritium Effluent & $30 \mathrm{Ci} / \mathrm{yr}$ \\
\hline
\end{tabular}

Within these parameters there would be experiments with the above listed materials under both yield and non-yield conditions. Tests with lithium hydride, depleted and highly enriched uranium, and other fissionable materials will occur in the target chamber in the same manner as all other tests (e.g., deuterium/tritium capsules in a hohlraum for indirect drive or without the hohlraum for direct drive). The diagnostics for these experiments would vary with the specific test. No new features would have to be added to the support facilities to field experiments with these materials.

For tests with plutonium ${ }^{10}$, an inner containment chamber, presently assumed to be fabricated from stainless steel (316), would be used to prevent the plutonium (and fission products) from being deposited on the main NIF target chamber, first wall, target positioner, or diagnostics. This inner containment would be brought from the Superblock and transported to NIF as a sealed and assembled unit. It would be transported in a shipping container and placed into the main target chamber through the large port on the chamber equator or through the bottom of the NIF target chamber. The target would be placed at target chamber center and the test performed using all or a subset of the laser beams. Once the test is complete, the inner chamber would be removed, placed in a shipping container and shipped off-site for disposal, or returned

\footnotetext{
${ }^{10}$ Other highly radioactive actinides, whose use is not currently envisioned, would also require containment. If used, the inventories of these materials would be limited such that their environmental impact (off-site accidents, worker exposure, etc. ) would not exceed the bounds defined here.
} 
to the Superblock for post-test examination and processing. The inner chamber, having been used in a single test, would then be placed in a shipping container and transported to the Nevada Test Site for disposal as low-level waste.

\subsubsection{Particulate Production}

As discussed previously, deposition of laser energy results in vaporization of the target, emission of $\mathrm{x}$-rays, and for shots including deuterium/ tritium targets, a release of neutrons. X-rays and unconverted laser light will also ablate material from nearby surfaces and components, creating particulate in the target chamber. The particulate created for the Proposed Action alternative, in addition to the No Action quantities, includes increased amounts of beryllium and depleted uranium, as well as lithium hydride, Highly Enriched Uranium (HEU), Th-232, Weapons Grade Plutonium (WG$\mathrm{Pu})^{11}$, and other materials used as tracers. Table 20 provides a summary of the particulate inventories (incremental to those given in Table 4) estimated for the Proposed Action alternative.

The in-chamber inventories provided in Table 20 are conservative estimates of the amount of material that would be present as particulate at the end of one year. More frequent than annual chamber cleaning would reduce the inventory for shots other than plutonium. The remainder of the unablated first-wall, debris shield, diagnostic, etc., components is solid material and is not vulnerable to release under any credible circumstances. Most of the gases that may be contained in targets or created during non-Pu shots, such as krypton, xenon, deuterium, and tritium will be removed through the high-vacuum cryopumps.

Table 20. Bounding Annual Particulate Inventories in the Target Chamber for the Proposed Action Alternative.

\begin{tabular}{cc}
\hline Material & Maximum Inventory \\
\hline $\mathrm{Be}$ & $20 \mathrm{~g}$ \\
$\mathrm{LiH}$ & $125 \mathrm{~g}$ \\
& \\
Depleted Uranium & $2.2 \mathrm{~g} / \mathrm{shot}^{12}$ \\
& $100 \mathrm{~g} / \mathrm{yr}^{13}$ \\
$\mathrm{U}-234$ & $1.8 \mathrm{E}-5 \mathrm{Ci} / \mathrm{yr}$ \\
$\mathrm{U}-235$ & $7.8 \mathrm{E}-7 \mathrm{Ci} / \mathrm{yr}$ \\
$\mathrm{U}-238$ & $3.4 \mathrm{E}-5 \mathrm{Ci} / \mathrm{yr}$
\end{tabular}

11 The assumed composition of weapons grade material is $0.02 \% \mathrm{Pu}-238,93.85 \% \mathrm{Pu}-239,5.8 \% \mathrm{Pu}-240,0.3 \% \mathrm{Pu}-241$, $0.015 \% \mathrm{Am}-241$, and $0.02 \% \mathrm{Pu}-242$. Other isotopic mixes can be used as long as their impacts are within the bounds described here.

12 The single-shot inventory limit results from the fission products created during a single high-yield shot (45 MJ), as well as build-up of the longer-lived fission products during one year of $1200-\mathrm{MJ}$ operation. Note that trace quantities of solid fission products will also be produced; they are not included here because of their very small impact.

13 This is the total quantity of depleted uranium that could be in the NIF target chamber at any one time. Individual targets for yield shots will be limited to $2.2 \mathrm{~g}$ for DU. 


\begin{tabular}{|c|c|}
\hline $\mathrm{HEU}^{14}$ & $\begin{array}{l}1.2 \mathrm{~g} / \text { shot }^{12} \\
100 \mathrm{~g} / \mathrm{yr}\end{array}$ \\
\hline U-234 & $6.9 \mathrm{E}-3 \mathrm{Ci} / \mathrm{yr}$ \\
\hline U-235 & $2.0 \mathrm{E}-4 \mathrm{Ci} / \mathrm{yr}$ \\
\hline $\mathrm{U}-238$ & $1.8 \mathrm{E}-6 \mathrm{Ci} / \mathrm{yr}$ \\
\hline Th-232 & $\begin{array}{l}7.9 \mathrm{~g} / \mathrm{shot} \\
450 \mathrm{~g} / \mathrm{yr} \\
1.0 \mathrm{E}-5 \mathrm{Ci} / \mathrm{yr}\end{array}$ \\
\hline $\begin{array}{l}\text { Tracer Elements, } \\
\text { Iodine is } \\
\text { representative }^{15}\end{array}$ & $\begin{array}{l}1.7 \mathrm{E}-3 \mathrm{~g} / \mathrm{shot} \\
0.1 \mathrm{~g} / \mathrm{yr}\end{array}$ \\
\hline $\begin{array}{l}\text { Inner Containment } \\
\text { Chamber }\end{array}$ & \\
\hline WG-Pu & $3 \mathrm{~g} /$ shot (non-yield) ${ }^{16}$ \\
\hline Pu-238 & $1.0 \mathrm{E}-2 \mathrm{Ci}$ \\
\hline $\mathbf{P u}-239$ & $1.8 \mathrm{E}-1 \mathrm{Ci}$ \\
\hline $\mathrm{Pu}-240$ & $4.0 \mathrm{E}-2 \mathrm{Ci}$ \\
\hline $\mathrm{Pu}-241$ & 9.1E-1 Ci \\
\hline $\mathrm{Pu}-242$ & $2.4 \mathrm{E}-6 \mathrm{Ci}$ \\
\hline Am-241 & $1.6 \mathrm{E}-3$ \\
\hline WG-Pu & $1 \mathrm{~g} /$ shot (yield) \\
\hline $\mathrm{Pu}-238$ & $3.4 \mathrm{E}-3 \mathrm{Ci}$ \\
\hline Pu-239 & $5.8 \mathrm{E}-2 \mathrm{Ci}$ \\
\hline $\mathrm{Pu}-240$ & 1.3E-2 Ci \\
\hline $\mathrm{Pu}-241$ & $3.0 \mathrm{E}-1 \mathrm{Ci}$ \\
\hline $\mathrm{Pu}-242$ & $7.9 \mathrm{E}-7$ \\
\hline $\mathrm{Am}-241$ & $5.2 \mathrm{E}-4 \mathrm{Ci}$ \\
\hline $\begin{array}{l}\text { Inner Chamber } \\
\text { Particulate (SS316) }\end{array}$ & $225 \mathrm{~g}$ \\
\hline
\end{tabular}

${ }^{14}$ Assumed composition is $93.5 \mathrm{wt} \% \mathrm{U}-235,5.4 \% \mathrm{U}-238$, and $1.1 \%$ U-234. Individual targets for yield shots will be limited to $1.2 \mathrm{~g}$ for $\mathrm{HEU}$.

15 Other possible tracer elements include: $\mathrm{Be}, \mathrm{Li}, \mathrm{O}, \mathrm{Ne}, \mathrm{Cl}, \mathrm{Ar}, \mathrm{Ti}, \mathrm{Cr}, \mathrm{Ni}, \mathrm{Cu}, \mathrm{As}, \mathrm{Br}, \mathrm{Kr}, \mathrm{Rb}, \mathrm{Y}, \mathrm{Zr}, \mathrm{Nb}, \mathrm{Mo}, \mathrm{Rh}, \mathrm{Ag}, \mathrm{I}$, $\mathrm{Xe}, \mathrm{Nd}, \mathrm{Sm}, \mathrm{Eu}, \mathrm{Tm}, \mathrm{Lu}, \mathrm{Hf}, \mathrm{Ta}, \mathrm{W}, \mathrm{Re}, \mathrm{Ir}, \mathrm{Au}, \mathrm{Tl}, \mathrm{Bi}$. These are bounded by the representative tracer and can be used in similar quantities. The quantity in the table assumes 60 shots $/ \mathrm{yr}$, each at $1.7 \mathrm{mg}$.

16 This is the maximum quantity of plutonium in a single shot and present in the facility at any one time. 


\subsubsection{Radioactive Materials Use/Production}

Particulate created in the target chamber will see neutrons from yield shots and be subject to neutron activation. Fissile and fissionable isotopes will also be subject to fission. Table 21 lists the prominent nuclides expected to result from neutron exposure of target materials in the chamber. As noted earlier, for non-Pu shots, radioactive particulate created in the target chamber will be transferred to the decontamination systems and waste streams. However, since many are short-lived species, the maximum inventories associated with particulate would be found in the target chamber shortly after the last shot and well before cleanup. By the time cleaning occurs or components are removed, the radioactive particulate inventory would have decayed to much smaller quantities. For plutonium shots, all post-shot material will be retained in the containment chamber. After retrieving any debris for analysis from inside the containment (performed in Superblock), the chamber and remaining contents will enter the waste stream.

The inventories in Table 21 are maximum inventories for the proposed action. For non-plutonium shots, they correspond to a final 45-MJ-yield shot, ending one year of shots with $1200-\mathrm{MJ}$ total yield. Shots of this magnitude (45 MJ) are not scheduled as part of the normal experimental plan. However, $45 \mathrm{MJ}$ is the maximum theoretical yield that could be obtained. The 45-MJ inventories are used here to bound all inventories of radioactive particulate and fission products. For plutonium non-yield shots, the inventories correspond to $3 \mathrm{~g}$ of weapons grade plutonium. For all plutonium shots, the containment vessel will only be used for a single shot. Consequently, the inventories for the yield shot case include $1 \mathrm{~g}$ of weapons grade plutonium and the fission products and activated particulate resulting from a single 45MJ shot (no build-up of fission products would occur in subsequent shots).

During DT fusion shots, the NIF will generate neutron activation products in the target bay air and beam tubes. The total annual inventories of these radioactive gases produced would not change for the proposed action.

Table 21. Estimated Maximum Mobilizable Radionuclide Inventories for the Proposed Action Alternative.

\begin{tabular}{|c|c|}
\hline Isotope & Quantity Ci \\
\hline \multicolumn{2}{|c|}{ Depleted uranium: ${ }^{17}$} \\
\hline U-234 & $1.8 \mathrm{E}-5$ \\
\hline U-235 & $7.8 \mathrm{E}-7$ \\
\hline $\mathrm{U}-238$ & $3.4 \mathrm{E}-5$ \\
\hline $\begin{array}{l}17 \text { Depleted uran } \\
\text { composition is } \\
\text { maximum qua } \\
\text { of } 2.2 \text { g) subjec } \\
\text { shots }(60 \text { @ } 20\end{array}$ & $\begin{array}{l}\text { slightly radioactive (half-life of U-238 (dominant isotope) is } 4.5 \mathrm{E} 9 \mathrm{yrs} \text { ). The assumed } \\
3,0.36 \% \text { U-235, and } 0.0028 \% \text { U-234. The quantities listed correspond to the } \\
\text { the proposed action of } 100 \mathrm{~g} \text {. Fission products result from a single target (maximum } \\
\text { on yield ( } 4.6 \mathrm{E} 16 \text { fissions) and include residual fission products from previous yield } \\
\text { in product inventories provided are peak post-shot inventories. }\end{array}$ \\
\hline
\end{tabular}




\begin{tabular}{cc}
$\mathrm{Kr}-83 \mathrm{~m}$ & $1.6 \mathrm{E}-1$ \\
$\mathrm{Kr}-85$ & $1.3 \mathrm{E}-4$ \\
$\mathrm{Kr}-85 \mathrm{~m}$ & $4.4 \mathrm{E}-1$ \\
$\mathrm{Kr}-87$ & 2.5 \\
$\mathrm{Kr}-88$ & 1.7 \\
$\mathrm{Nb}-98$ & $1.3 \mathrm{E} 3$ \\
$\mathrm{I}-131$ & $6.2 \mathrm{E}-2$ \\
$\mathrm{I}-132$ & $1.6 \mathrm{E}-1$ \\
$\mathrm{I}-132 \mathrm{~m}$ & $2.0 \mathrm{E}-3$ \\
$\mathrm{I}-133$ & $6.7 \mathrm{E}-1$ \\
$\mathrm{I}-133 \mathrm{~m}$ & $1.1 \mathrm{E} 1$ \\
$\mathrm{I}-134$ & $7.9 \mathrm{E} 0$ \\
$\mathrm{I}-134 \mathrm{~m}$ & 4.0 \\
$\mathrm{I}-135$ & 2.3 \\
$\mathrm{I}-136$ & $2.9 \mathrm{E} 2$ \\
$\mathrm{Te}-134$ & $2.3 \mathrm{E} 1$ \\
$\mathrm{Xe}-133$ & $1.3 \mathrm{E}-1$ \\
$\mathrm{Xe}-133 \mathrm{~m}$ & $5.3 \mathrm{E}-3$ \\
$\mathrm{Xe}-134 \mathrm{~m}$ & $1.6 \mathrm{E} 1$ \\
$\mathrm{Xe}-135$ & $7.1 \mathrm{E}-1$ \\
$\mathrm{Xe}-135 \mathrm{~m}$ & $3.2 \mathrm{E}-1$ \\
$\mathrm{Xe}-137$ & $1.7 \mathrm{E} 2$ \\
$\mathrm{Xe}-138$ & $5.6 \mathrm{E} 2$ \\
\hline
\end{tabular}

HEU: ${ }^{18}$

U-234 $6.9 \mathrm{E}-3$

U-235 2.0E-4

$\mathrm{U}-238 \quad 1.8 \mathrm{E}-6$

$\mathrm{Kr}-87$

$\mathrm{Kr}-88$

$\mathrm{Nb}-98 \quad 1.2 \mathrm{E} 3$

I-131 5.1E-2

$\mathrm{I}-132 \quad 1.3 \mathrm{E}-1$

$\mathrm{I}-132 \mathrm{~m} \quad 3.0 \mathrm{E}-2$

$\mathrm{I}-133 \quad 6.1 \mathrm{E}-1$

$\mathrm{I}-133 \mathrm{~m} \quad 9.8 \mathrm{E} 1$

I-134 7.9

I-134m $1.7 \mathrm{E} 1$

I-135 2.1

$\mathrm{I}-136 \quad 1.8 \mathrm{E} 2$

Te-134 2.0E1

Xe-133 1.2E-1

${ }^{18} \mathrm{HEU}$ is already slightly radioactive (half-life of U-235 (dominant isotope) is $7.0 \mathrm{E} 8 \mathrm{yrs}$ ). The assumed composition is $93.5 \mathrm{wt} \% \mathrm{U}-235,5.4 \% \mathrm{U}-238$, and $1.1 \% \mathrm{U}-234$. The quantity listed corresponds to the maximum quantity used for the proposed action of $100 \mathrm{~g}$. Fission products result from a single target (maximum of $1.2 \mathrm{~g}$ ) subject to a 45-MJ fusion yield (4.6E16 fissions) and include residual fission products from previous yield shots (60 @ 20 MJ). The fission product inventories provided are peak post-shot inventories. 


$\begin{array}{cc}\mathrm{Xe}-133 \mathrm{~m} & 4.9 \mathrm{E}-3 \\ \mathrm{Xe}-134 \mathrm{~m} & 3.2 \mathrm{E} 2 \\ \mathrm{Xe}-135 & 6.7 \mathrm{E}-1 \\ \mathrm{Xe}-135 \mathrm{~m} & 1.7 \\ \mathrm{Xe}-137 & 1.6 \mathrm{E} 2 \\ \mathrm{Xe}-138 & 5.6 \mathrm{E} 1\end{array}$

Th-232: ${ }^{19}$

Th-232 1.0E-5

$\mathrm{Kr}-83 \mathrm{~m} \quad 9.2 \mathrm{E}-1$

$\mathrm{Kr}-85 \quad$ 8.7E-4

$\mathrm{Kr}-85 \mathrm{~m} \quad 3.0$

$\mathrm{Kr}-87 \quad 1.1 \mathrm{E} 1$

$\mathrm{Kr}-88$

$\mathrm{Nb}-98 \quad 8.2 \mathrm{E} 2$

$\mathrm{I}-131 \quad 3.4 \mathrm{E}-2$

$\mathrm{I}-132$

$\mathrm{I}-132 \mathrm{~m} \quad 2.3 \mathrm{E}-3$

$\mathrm{I}-133 \quad 4.6 \mathrm{E}-1$

$\mathrm{I}-133 \mathrm{~m} \quad 1.3 \mathrm{E} 1$

$\mathrm{I}-134$

$\mathrm{I}-134 \mathrm{~m}$

I-135 2.0

I-136 2.5E2

Te-134 1.8E1

Xe-133 9.0E-2

$\mathrm{Xe}-133 \mathrm{~m} \quad 3.7 \mathrm{E}-3$

$\mathrm{Xe}-134 \mathrm{~m} \quad 2.2 \mathrm{E} 1$

$\mathrm{Xe}-135$

$\mathrm{Xe}-135 \mathrm{~m} \quad 2.8 \mathrm{E}-1$

$\mathrm{Xe}-137 \quad 1.8 \mathrm{E} 2$

$\mathrm{Xe}-138 \quad 6.2 \mathrm{E} 1$

Tracers: Iodine is

bounding and

representative

I-124

I-125

$6.2 \mathrm{E}-2$

I-126

$6.4 \mathrm{E}-2$

$1.5 \mathrm{E}-1$

Inner Chamber,

Weapons Grade

Plutonium (nonyield)

${ }^{19} \mathrm{Th}-232$ is already slightly radioactive (half-life of $1.4 \mathrm{E} 10 \mathrm{yrs}$ ). The quantity listed corresponds to the maximum quantity used for the proposed action of $450 \mathrm{~g}$. Fission products result from a single target (maximum of $7.9 \mathrm{~g}$ ) subject to a 45-MJ fusion yield (5.3E16 fissions) and include residual fission products from previous yield shots (60 @ $20 \mathrm{MJ}$ ). The fission product inventories provided are peak post-shot inventories. 
$\mathrm{Pu}-238$

Pu-239

1.0E-2

$\mathrm{Pu}-240$

$1.8 \mathrm{E}-1$

$\mathrm{Pu}-241$

4.0E-2

Pu-242

9.1E-1

Am-241

$2.4 \mathrm{E}-6$

$1.6 \mathrm{E}-3$

Inner Container, Weapons Grade

Plutonium (with yield ${ }^{20}$ )

$\mathrm{Pu}-238$

$3.4 \mathrm{E}-3$

Pu-239

$5.8 \mathrm{E}-2$

Pu-240

$1.3 \mathrm{E}-2$

Pu-241

3.0E-1

$\mathrm{Pu}-242$

7.9E-7

Am-241

$5.2 \mathrm{E}-4$

$\mathrm{Kr}-83 \mathrm{~m}$

$1.1 \mathrm{E}-1$

$\mathrm{Kr}-85$

3.0E-6

$\mathrm{Kr}-85 \mathrm{~m}$

2.6E-1

$\mathrm{Kr}-87$

1.6

$\mathrm{Kr}-88$

9.6E-1

$\mathrm{Nb}-98$

$1.2 \mathrm{E}+3$

I-131

3.7E-2

I-132

1.5E-1

I-132m

$1.8 \mathrm{E}-1$

I-133

6.4E-1

I-133m

$3.4 \mathrm{E}+2$

I-134

8.3

I-134m

$4.1 \mathrm{E}+1$

I-135

2.1

I-136

$1.3 \mathrm{E}+2$

Te-134

$1.5 \mathrm{E}+1$

Xe-133

8.3E-2

Xe-133m

4.8E-3

Xe-134m

$1.7 \mathrm{E}+3$

Xe-135

7.6E-1

Xe-135m

6.0

Xe-137

$1.7 \mathrm{E}+2$

Xe-138

$4.6 \mathrm{E}+1$

20 The assumed composition of weapons grade material is $0.02 \% \mathrm{Pu}-238,93.85 \% \mathrm{Pu}-239,5.8 \% \mathrm{Pu}-240,0.3 \% \mathrm{Pu}-241$, $0.015 \% \mathrm{Am}-241$, and $0.02 \% \mathrm{Pu}-242$. Other isotopic mixes can be used as long as their impacts are within the bounds described here. The fission products result from a single target (maximum of $1 \mathrm{~g}$ ) subject to a 45-MJ fusion yield (3.2E16 fissions). Since only a single shot would occur within a containment vessel, only the fission products resulting from this single shot are included. The fission product inventories are peak post-shot inventories. 
Inner Chamber
Particulate

$\begin{array}{cc}\text { Al-28 } & 2.1 \mathrm{E}-1 \\ \mathrm{Si}-31 & 8.1 \mathrm{E}-5 \\ \mathrm{P}-30 & 4.5 \mathrm{E}-4 \\ \mathrm{~V}-49 & 1.3 \mathrm{E}-6 \\ \mathrm{Cr}-49 & 2.0 \mathrm{E}-4 \\ \mathrm{Cr}-51 & 1.3 \mathrm{E}-4 \\ \mathrm{Mn}-52 \mathrm{~m} & 1.5 \mathrm{E}-5 \\ \mathrm{Mn}-54 & 8.7 \mathrm{E}-6 \\ \mathrm{Mn}-56 & 5.8 \mathrm{E}-2 \\ \mathrm{Fe}-55 & 2.0 \mathrm{E}-5 \\ \mathrm{Co}-57 & 1.5 \mathrm{E}-5 \\ \mathrm{Co}-58 & 3.5 \mathrm{E}-5 \\ \mathrm{Co}-58 \mathrm{~m} & 5.1 \mathrm{E}-3 \\ \mathrm{Co}-60 \mathrm{~m} & 3.2 \mathrm{E}-2 \\ \mathrm{Co}-61 & 2.2 \mathrm{E}-4 \\ \mathrm{Co}-62 \mathrm{~m} & 4.8 \mathrm{E}-4 \\ \mathrm{Ni}-57 & 1.3 \mathrm{E}-4 \\ \mathrm{Ni}-65 & 1.6 \mathrm{E}-5 \\ \mathrm{Nb}-96 & 3.9 \mathrm{E}-6 \\ \mathrm{Nb}-97 & 2.8 \mathrm{E}-5 \\ \mathrm{Nb}-97 \mathrm{~m} & 5.5 \mathrm{E}-4 \\ \mathrm{Nb}-98 & 1.6 \mathrm{E}-2 \\ \mathrm{Mo}-93 \mathrm{~m} & 1.3 \mathrm{E}-6 \\ \mathrm{Mo}-99 & 5.5 \mathrm{E}-5 \\ \mathrm{Tc}-99 \mathrm{~m} & 2.2 \mathrm{E}-5\end{array}$

These maximum inventories would not be simultaneously present. One of these possibilities (either DU+fission products, U-235+fission products, Th-232+fission products, WG-Pu (3 g), WG-Pu (1 g)+fission products, or tracer activation products) will set the radiological bound. Each of these possibilities should be considered as a potential source term for the bounding accident, see Section 4.3. Note that a year of experiments involving a combination of different shots would be possible as long as the combination remains within the bounds defined here.

\subsection{Environmental Impacts During Routine Operations}

\subsubsection{Radiological Emissions and Worker Exposures During Routine Operations}

Releases of activated target bay gases would be unchanged for the proposed action. However, fission products would be created during shots involving fissile or fissionable materials, and some would be routinely released to the environment as part of normal operations. Many are short-lived, and will decay while being held on the cryopumps. 
Alternately, they can be discharged to the accumulation tank and held until most have decayed. Some longer-lived gaseous fission products, such as Kr-85 (10.7 yrs half-life), will likely be released to the environment. Fission products that are solids will be retained in the target chamber (very small amounts). Other semi-volatile fission products (e.g., iodine isotopes) can be captured on charcoal filters, which are at least $99 \%$ efficient, thus minimizing any release of these radionuclides to the environment. For the purpose of this analysis, a conservative efficiency of $95 \%$ has been assumed for the filters. Thus, $5 \%$ of the mobilizable iodine isotopes is assumed to be released. The release point is the stack with a $35-\mathrm{m}$ height, $1.1-\mathrm{m}$ diameter, and a $7.3-\mathrm{m} / \mathrm{s}$ exit velocity. The MEI would be located at the veterinarian facility, $400 \mathrm{~m}$ from the NIF elevated release point. Table 22 lists the maximum annual quantities of fission products expected to be released for the proposed action. This represents the inventories resulting from 1200-MJ annual yield, which are assumed to be uniformly released to the environment over one year. Three possible sources of these additional fission product emissions are provided: HEU, DU, and Th-232, with HEU as the limiting case.

For plutonium shots with yield, fission products would be contained within the containment vessel. Some longer-lived gases would remain when the vessel is opened to retrieve debris for analysis. These, along with remaining semi-volatile fission products would be released from the Superblock. There would be a maximum of four plutonium yield shots per year, at yields up to $20 \mathrm{MJ} .{ }^{21}$ The fission product inventories created from these plutonium shots would be bounded by the HEU fission products routinely released and listed in Table 22 below.

Personnel will be exposed to prompt radiation during NIF yield operations. Also, during high-yield operations, tasks that must be performed within the NIF target bay or that involve handling of materials that have been inside the target bay during highyield experiments will result in some level of radiation dose. This will not change from the No Action Alternative. For plutonium non-yield shots, an additional exposure would occur during placement of the containment chamber into the main NIF chamber, and then again, during its removal after the shot. During this time, personnel are assumed to be in close proximity to a large, open chamber port. Since they will have a line-of-sight view to the activated target chamber interior (activated as a result of previous shots), they will receive some amount of exposure. The containment chamber would not be activated during non-yield shots.

21 There will also be up to 10 non-yield shots per year, but these will not contribute to any additional routine radioactive airborne emissions. 
Table 22. Annual Additional Routine Radioactive Airborne Emissions for Proposed Action (Fission Products). 1.2-gram HEU/target: 2E16 fissions per 20-MJ shot, 60 shots per year.

\begin{tabular}{|c|c|c|c|c|}
\hline Nuclide & $\begin{array}{c}\begin{array}{c}\text { Maximum } \\
\text { production }\end{array} \\
(\mathrm{Ci} / 20 \mathrm{MJ})\end{array}$ & $\begin{array}{l}\text { After } 5 \text { days } \\
\text { holdup in } \\
\text { cryopumps } \\
\text { (Ci/20MJ) }\end{array}$ & $\begin{array}{l}\text { Annual amount } \\
\text { available for } \\
\text { release } \\
\text { (Ci/1200 MJ) }\end{array}$ & $\begin{array}{c}\text { Annual air } \\
\text { effluents via } \\
\text { charcoal filter } \\
\text { (Ci/1200 MJ) }\end{array}$ \\
\hline${ }^{83 m} \mathrm{Kr}$ & $1.80 \mathrm{E}-01$ & $1.76 \mathrm{E}-15$ & $1.05 \mathrm{E}-13$ & $1.05 \mathrm{E}-13$ \\
\hline${ }^{85} \mathrm{Kr}$ & $5.75 E-06$ & $5.76 \mathrm{E}-06$ & $3.46 \mathrm{E}-04$ & $3.46 \mathrm{E}-04$ \\
\hline${ }^{85 m} \mathrm{Kr}$ & $5.22 \mathrm{E}-01$ & $4.88 \mathrm{E}-09$ & $2.93 \mathrm{E}-07$ & $2.93 \mathrm{E}-07$ \\
\hline${ }^{87} \mathrm{Kr}$ & $2.50 \mathrm{E}+00$ & $0.00 \mathrm{E}+00$ & $0.00 \mathrm{E}+00$ & $0.00 \mathrm{E}+00$ \\
\hline${ }^{88} \mathrm{Kr}$ & $1.88 \mathrm{E}+00$ & $3.78 \mathrm{E}-13$ & $2.27 \mathrm{E}-11$ & $2.27 \mathrm{E}-11$ \\
\hline${ }^{89} \mathrm{Kr}$ & $1.27 \mathrm{E}+02$ & $0.00 \mathrm{E}+00$ & $0.00 \mathrm{E}+00$ & $0.00 \mathrm{E}+00$ \\
\hline${ }^{131} \mathbf{I}$ & $4.36 \mathrm{E}-02$ & $3.10 \mathrm{E}-02$ & $1.86 \mathrm{E}+00$ & $9.28 \mathrm{E}-02$ \\
\hline${ }^{132} I$ & $1.62 \mathrm{E}-01$ & $6.42 \mathrm{E}-02$ & $3.85 E+00$ & $1.93 \mathrm{E}-01$ \\
\hline${ }^{132 m} \mathrm{I}$ & $2.32 \mathrm{E}-03$ & $0.00 \mathrm{E}+00$ & $0.00 \mathrm{E}+00$ & $0.00 \mathrm{E}+00$ \\
\hline${ }^{133} \mathrm{I}$ & $9.07 \mathrm{E}-01$ & $1.87 \mathrm{E}-02$ & $1.12 \mathrm{E}+00$ & $5.60 \mathrm{E}-02$ \\
\hline${ }_{133 m_{I}}$ & $1.58 \mathrm{E}+00$ & $0.00 \mathrm{E}+00$ & $0.00 \mathrm{E}+00$ & $0.00 \mathrm{E}+00$ \\
\hline${ }^{134} \mathbf{I}$ & $9.04 E+00$ & $0.00 \mathrm{E}+00$ & $0.00 \mathrm{E}+00$ & $0.00 \mathrm{E}+00$ \\
\hline${ }^{134 m} \mathrm{I}$ & $4.76 \mathrm{E}+00$ & $0.00 \mathrm{E}+00$ & $0.00 \mathrm{E}+00$ & $0.00 \mathrm{E}+00$ \\
\hline${ }^{135} \mathrm{I}$ & $2.58 \mathrm{E}+00$ & $9.32 \mathrm{E}-06$ & $6.08 \mathrm{E}-04$ & $2.80 \mathrm{E}-05$ \\
\hline${ }^{136} \mathrm{I}$ & $3.47 E+02$ & $0.00 \mathrm{E}+00$ & $0.00 \mathrm{E}+00$ & $0.00 \mathrm{E}+00$ \\
\hline${ }^{131} \mathrm{Xe}$ & $1.52 \mathrm{E}-04$ & $1.01 E-04$ & $6.08 \mathrm{E}-03$ & $6.08 \mathrm{E}-03$ \\
\hline${ }^{133} \mathrm{Xe}$ & $1.14 \mathrm{E}-01$ & $9.85 \mathrm{E}-02$ & $5.92 \mathrm{E}+00$ & $5.92 \mathrm{E}+00$ \\
\hline${ }^{133 m} \mathrm{Xe}$ & $6.23 \mathrm{E}-03$ & $3.56 \mathrm{E}-03$ & $2.14 \mathrm{E}-01$ & $2.14 \mathrm{E}-01$ \\
\hline${ }^{134 m} \mathrm{Xe}$ & $1.30 \mathrm{E}+00$ & $0.00 \mathrm{E}+00$ & $0.00 \mathrm{E}+00$ & $0.00 \mathrm{E}+00$ \\
\hline${ }^{135} \mathrm{Xe}$ & $8.28 \mathrm{E}-01$ & $7.45 \mathrm{E}-04$ & $4.46 \mathrm{E}-02$ & $4.46 \mathrm{E}-02$ \\
\hline${ }^{135 m} \times e$ & $3.68 \mathrm{E}-01$ & $1.5 \mathrm{E}-06$ & $9.02 \mathrm{E}-05$ & $9.02 \mathrm{E}-05$ \\
\hline${ }^{137} \mathrm{Xe}$ & $1.92 \mathrm{E}+02$ & $0.00 \mathrm{E}+00$ & $0.00 \mathrm{E}+00$ & $0.00 \mathrm{E}+00$ \\
\hline Total & $6.91 \mathrm{E}+02$ & 2.17E-01 & $1.30 \mathrm{E}+01$ & $6.52 E+00$ \\
\hline
\end{tabular}

* The effluents from the cryopumps during regeneration and the from the target chamber when bringing to air will be passed through 2-in-thick charcoal filters to remove iodine isotopes, with $99 \%$ being collected by charcoal bed. Only $95 \%$ retention has been assumed for conservatism.

Appropriate protective measures for plutonium exposure will be used during postshot activities. Thus, no additional routine exposure is expected if the chamber needs to be accessed to retrieve debris for analysis or during packaging of the chamber as waste. For 10 non-yield plutonium shots per year, the additional exposure incurred during chamber placement and removal is estimated to be no more than 1 person-rem per year. For plutonium yield shots, an additional exposure would occur during handling of the containment chamber (placement and removal), accessing it to retrieve debris for 
analysis, and packaging it as waste. This dose occurs mostly as a result of exposure to the activated containment chamber. This additional dose was estimated assuming four plutonium yield shots per year, @ 20-MJ each. It was estimated that an additional 3 person-rem/yr of worker exposure could result from these plutonium yield tests.

In addition, a worker dose would be incurred during routine decontamination activities. This would include handling of contaminated/activated items, disassembling them (if needed), and processing them through the decontamination systems. This dose is largely related to the cleaning frequency, which is unchanged (at once per year). Thus, this component of the worker dose is not expected for the proposed action.

Radiation exposure in radiologically controlled areas will be kept ALARA through facility and equipment design and administrative controls.

\subsubsection{Transportation of Targets}

NIF targets are expected to come from two sources. Most of the targets will be provided from an on-site source, such as LLNL Superblock. The other source would be LANL. Targets for the proposed action would include quantities of DU, HEU, Th-232, or WG-Pu, in addition to tritium. There would be a total of 14 plutonium shots in a year (10 non-yield, containing up to $3 \mathrm{~g}$ of $\mathrm{Pu}$, and 4 yield, containing up to $1 \mathrm{~g}$ of $\mathrm{Pu}$ ). An additional bounding scenario for the Proposed Action would be the transportation of one plutonium target (up to $3 \mathrm{~g}$ ) from its source. Post-shot, the containment vessel would be transported on site from NIF to the Superblock. The consequences of any post-shot transportation would be bound by the accident scenario considered in Section 4.3.1.

Impacts from routine transportation of plutonium targets would not be expected, because there would be no detectable levels of radiation outside the packages carrying the target.

Target fill facilities will have their own NEPA determinations and safety basis documentation. The risk and consequence evaluation of transportation to NIF is provided, based on distance traveled and a bounding scenario involving a vehicle crash.

\subsubsection{Waste Generated During NIF Operations}

Many of the waste streams would be unchanged for the proposed action, as they are not directly related to the proposed changes in materials used for shots. Since fission products may be produced from some yield shots, it is expected that there would be a small increase in LLW related to filters. Charcoal filters would be used to capture iodine isotopes, and these would need periodic, although infrequent, replacement. Other waste streams, such as target chamber hardware or decontamination wastes, would not be expected to change since the same cleaning frequency as the No Action Alternative seems appropriate. For plutonium shots, disposal of the containment vessel will increase the low-level radioactive waste stream. The additional waste has been 
estimated based on 14 plutonium shots per year ( 4 with yield, 10 without yield). Each container occupies approximately $8.5 \mathrm{~m}^{3}$ of space (including void volume). Because it is expected (in most cases) that the container will leave LLNL from the Superblock, it appears in the Superblock (B331) waste stream. Table 23 summarizes the estimated waste streams for the proposed action.

Table 23. National Ignition Facility Waste Estimates for Low-Level, Mixed, and Hazardous Wastes (Per Year of National Ignition Facility Operation) for the Proposed Action

Alternative.

\begin{tabular}{|c|c|c|c|c|c|c|c|}
\hline & \multirow[b]{2}{*}{ Source of Waste } & \multicolumn{2}{|c|}{$\begin{array}{c}\text { Low-Level } \\
\text { Radioactive }\end{array}$} & \multicolumn{2}{|c|}{ Mixed } & \multicolumn{2}{|c|}{ Hazardous } \\
\hline & & $\begin{array}{c}\text { Solid } \\
\left(\mathrm{m}^{3}\right)\end{array}$ & $\begin{array}{c}\text { Liquid } \\
\left(\mathrm{m}^{3}\right)\end{array}$ & $\begin{array}{l}\text { Solid } \\
\left(\mathrm{m}^{3}\right)\end{array}$ & $\begin{array}{c}\text { Liquid } \\
\left(\mathrm{m}^{3}\right)\end{array}$ & $\begin{array}{l}\text { Solid } \\
\left(\mathrm{m}^{3}\right)\end{array}$ & $\begin{array}{c}\text { Liquid } \\
\left(\mathrm{m}^{3}\right)\end{array}$ \\
\hline 1. & Tritium processing & 1.2 & & 0.003 & & & \\
\hline 2. & Wipe cleaning & 3.3 & 0.3 & 1.0 & & 1.0 & \\
\hline 3. & HEPA filters/pre-filters & 0.27 & & & & & \\
\hline 4. & Waste hardware & $24^{22}$ & & 0.5 & & & \\
\hline 5. & Chemical treatment/decon & & 1.3 & 0.3 & 4.9 & & 1.5 \\
\hline 6. & Waste oils/equipment & 0.060 & & & 0.2 & 7.5 & 0.2 \\
\hline \multirow[t]{3}{*}{7.} & General chemicals & & & & & & 4.6 \\
\hline & Total/yr & 29 & 1.6 & 1.8 & 5.1 & 8.5 & 6.3 \\
\hline & Change from No Action & -22 & - & - & - & - & - \\
\hline
\end{tabular}

\subsection{Environmental Impacts from Accidents}

This section describes the bounding accidents for NIF for the Proposed Action Alternative. Also included are the source terms and accident release characteristics.

\subsubsection{Radiological Release from the Facility}

The proposed action would not introduce any new types of accident scenarios. Thus, the scenarios considered for the No Action Alternative have been examined with a revised source term for the Proposed Action. Because of facility inventory limits (to maintain hazard classification), some materials will not be simultaneously allowed into the facility. Strict inventory controls will be in place and adhered to. Several possible source terms are provided. Consequences should be assessed for the one that will result in the bounding off-site consequences.

\section{Source Terms}

Radioactive inventories vulnerable to release include: (1) activated gases; (2) activated particulate in the target chamber; (3) tritium; and for fissile/fissionable materials, (4) the source material (and for yield shots, associated fission products). For

22 Additional solid LLW would result from the containment vessel used for plutonium shots. Because the vessel will in most (if not all) cases leave the LLNL site after post-shot processing in B331, this source of waste appears in the Superblock (B331) waste stream. The solid LLW stream quantity for 10 non-yield and 4 yield shots is estimated to be $120 \mathrm{~m}^{3} / \mathrm{yr}$. 
the Proposed Action, there will be no change in the activated gas or tritium source terms. The activated particulate inventory in the target chamber will change, based on the new materials proposed. In addition to the target chamber particulate, gaseous and semi-volatile fission products would be present immediately after the shot and would be vulnerable to release. Alternately, inventories from tracers that are part of the proposed action could also be present. Plutonium shots would add isotopes making up the weapons grade material, and for yield shots, associated fission products and activated particulate formed in the containment chamber. As noted above, these source terms would not all be simultaneously present. Consequences should be assessed for the type of shot that will result in the bounding off-site consequences. The possible bounding target chamber inventories that would result for the Proposed Action are summarized in Table 24.

Table 24. Possible Bounding Radiological Accident Source Terms for the Proposed Action Alternative

\begin{tabular}{|c|c|c|c|}
\hline Radionuclide & Quantity Present (Ci) & Release Fraction & Quantity Released (Ci) \\
\hline \multicolumn{4}{|c|}{ Depleted uranium: ${ }^{23}$} \\
\hline $\mathrm{U}-234$ & $1.8 \mathrm{E}-5$ & $1 \mathrm{E}-3$ & $1.7 \mathrm{E}-8$ \\
\hline U-235 & $7.8 \mathrm{E}-7$ & $1 \mathrm{E}-3$ & $8.0 \mathrm{E}-10$ \\
\hline $\mathrm{U}-238$ & $3.4 \mathrm{E}-5$ & $1 \mathrm{E}-3$ & $3.2 \mathrm{E}-8$ \\
\hline $\mathrm{Kr}-83 \mathrm{~m}$ & $1.6 \mathrm{E}-1$ & 1.0 & $1.5 \mathrm{E}-1$ \\
\hline $\mathrm{Kr}-85$ & $1.3 \mathrm{E}-4$ & 1.0 & $1.2 \mathrm{E}-4$ \\
\hline $\mathrm{Kr}-85 \mathrm{~m}$ & $4.4 \mathrm{E}-1$ & 1.0 & $4.2 \mathrm{E}-1$ \\
\hline $\mathrm{Kr}-87$ & 2.5 & 1.0 & 2.4 \\
\hline $\mathrm{Kr}-88$ & 1.7 & 1.0 & 1.6 \\
\hline $\mathrm{Nb}-98$ & $1.3 \mathrm{E} 3$ & $1 \mathrm{E}-3$ & 1.2 \\
\hline $\mathrm{I}-131$ & $6.2 \mathrm{E}-2$ & 0.5 & $3.0 \mathrm{E}-2$ \\
\hline $\mathrm{I}-132$ & $1.6 \mathrm{E}-1$ & 0.5 & $7.5 \mathrm{E}-2$ \\
\hline $\mathrm{I}-132 \mathrm{~m}$ & $2.0 \mathrm{E}-3$ & 0.5 & $9.5 \mathrm{E}-4$ \\
\hline $\mathrm{I}-133$ & $6.7 \mathrm{E}-1$ & 0.5 & $3.2 \mathrm{E}-1$ \\
\hline $\mathrm{I}-133 \mathrm{~m}$ & $1.1 \mathrm{E} 1$ & 0.5 & 5.0 \\
\hline $\mathrm{I}-134$ & 7.9 & 0.5 & 3.8 \\
\hline $\mathrm{I}-134 \mathrm{~m}$ & 4.0 & 0.5 & 1.9 \\
\hline $\mathrm{I}-135$ & 2.3 & 0.5 & 1.1 \\
\hline $\mathrm{I}-136$ & $2.9 \mathrm{E} 2$ & 0.5 & $1.4 \mathrm{E} 2$ \\
\hline $\mathrm{Te}-134$ & 2.3E1 & $1 \mathrm{E}-3$ & $2.2 \mathrm{E}-2$ \\
\hline Xe-133 & $1.3 \mathrm{E}-1$ & 1.0 & $1.2 \mathrm{E}-1$ \\
\hline $\mathrm{Xe}-133 \mathrm{~m}$ & $5.3 \mathrm{E}-3$ & 1.0 & $5.0 \mathrm{E}-3$ \\
\hline $\mathrm{Xe}-134 \mathrm{~m}$ & $1.6 \mathrm{E} 1$ & 1.0 & $1.5 \mathrm{E} 1$ \\
\hline $\mathrm{Xe}-135$ & $7.1 E-1$ & 1.0 & $6.7 \mathrm{E}-1$ \\
\hline
\end{tabular}

23 Depleted uranium is already slightly radioactive (half-life of U-238 (dominant isotope) is $4.5 \mathrm{E} 9 \mathrm{yrs}$ ). The assumed composition is: $99.64 \% \mathrm{U}-238,0.36 \% \mathrm{U}-235$, and $0.0028 \% \mathrm{U}-234$. The quantities listed correspond to the maximum quantity used for the proposed action of $100 \mathrm{~g}$. Fission products result from a single target (maximum of $2.2 \mathrm{~g}$ ) subject to 45-MJ fusion yield (4.6E16 fissions) and include residual fission products from previous yield shots $(60 @ 20 \mathrm{MJ})$. The fission product inventories are peak post-shot inventories. 


\begin{tabular}{|c|c|c|c|}
\hline Xe-135m & $3.2 \mathrm{E}-1$ & 1.0 & $3.0 \mathrm{E}-1$ \\
\hline Xe-137 & 1.7E2 & 1.0 & $1.6 \mathrm{E} 2$ \\
\hline Xe-138 & $5.6 \mathrm{E} 1$ & 1.0 & $5.3 \mathrm{E} 1$ \\
\hline \multicolumn{4}{|l|}{ HEU: ${ }^{24}$} \\
\hline U-234 & $6.9 \mathrm{E}-3$ & $1 \mathrm{E}-3$ & $6.9 \mathrm{E}-6$ \\
\hline U-235 & $2.0 \mathrm{E}-4$ & $1 \mathrm{E}-3$ & 2.0E-7 \\
\hline $\mathrm{U}-238$ & $1.8 \mathrm{E}-6$ & $1 \mathrm{E}-3$ & $1.8 \mathrm{E}-9$ \\
\hline $\mathrm{Kr}-87$ & 4.1 & 1.0 & 4.1 \\
\hline $\mathrm{Kr}-88$ & 2.6 & 1.0 & 2.6 \\
\hline $\mathrm{Nb}-98$ & $1.2 \mathrm{E} 3$ & $1 \mathrm{E}-3$ & 1.2 \\
\hline $\mathrm{I}-131$ & $5.1 \mathrm{E}-2$ & 0.5 & $2.6 \mathrm{E}-2$ \\
\hline $\mathrm{I}-132$ & $1.3 \mathrm{E}-1$ & 0.5 & $6.5 \mathrm{E}-2$ \\
\hline $\mathrm{I}-132 \mathrm{~m}$ & $3.0 \mathrm{E}-2$ & 0.5 & $1.5 \mathrm{E}-2$ \\
\hline $\mathrm{I}-133$ & $6.1 \mathrm{E}-1$ & 0.5 & 3.1E-1 \\
\hline $\mathrm{I}-133 \mathrm{~m}$ & $9.8 \mathrm{E} 1$ & 0.5 & $4.9 \mathrm{E} 1$ \\
\hline I-134 & 7.9 & 0.5 & 4.0 \\
\hline $\mathrm{I}-134 \mathrm{~m}$ & $1.7 \mathrm{E} 1$ & 0.5 & 8.5 \\
\hline I-135 & 2.1 & 0.5 & 1.1 \\
\hline I-136 & $1.8 \mathrm{E} 2$ & 0.5 & $9.0 \mathrm{E} 1$ \\
\hline Te-134 & $2.0 \mathrm{E} 1$ & $1 \mathrm{E}-3$ & $2.0 \mathrm{E}-2$ \\
\hline Xe-133 & $1.2 \mathrm{E}-1$ & 1.0 & $1.2 \mathrm{E}-1$ \\
\hline $\mathrm{Xe}-133 \mathrm{~m}$ & $4.9 \mathrm{E}-3$ & 1.0 & $4.9 \mathrm{E}-3$ \\
\hline$X e-134 m$ & $3.2 \mathrm{E} 2$ & 1.0 & $3.2 \mathrm{E} 2$ \\
\hline Xe-135 & 6.7E-1 & 1.0 & 6.7E-1 \\
\hline $\mathrm{Xe}-135 \mathrm{~m}$ & 1.7 & 1.0 & 1.7 \\
\hline$X e-137$ & $1.6 \mathrm{E} 2$ & 1.0 & $1.6 \mathrm{E} 2$ \\
\hline Xe-138 & $5.6 \mathrm{E} 1$ & 1.0 & $5.6 \mathrm{E} 1$ \\
\hline \multicolumn{4}{|l|}{ Th-232:25 } \\
\hline Th-232 & $1.0 \mathrm{E}-5$ & $1 \mathrm{E}-3$ & $1.0 \mathrm{E}-8$ \\
\hline $\mathrm{Kr}-83 \mathrm{~m}$ & $9.2 \mathrm{E}-1$ & 1.0 & $9.2 \mathrm{E}-1$ \\
\hline $\mathrm{Kr}-85$ & 8.7E-4 & 1.0 & 8.7E-4 \\
\hline $\mathrm{Kr}-85 \mathrm{~m}$ & 3.0 & 1.0 & 3.0 \\
\hline $\mathrm{Kr}-87$ & $1.1 \mathrm{E} 1$ & 1.0 & 1.1E1 \\
\hline $\mathrm{Kr}-88$ & 5.6 & 1.0 & 5.6 \\
\hline $\mathrm{Nb}-98$ & $8.2 \mathrm{E} 2$ & $1 \mathrm{E}-3$ & $8.2 \mathrm{E}-1$ \\
\hline I-131 & $3.4 \mathrm{E}-2$ & 0.5 & $1.7 \mathrm{E}-2$ \\
\hline I-132 & $9.1 \mathrm{E}-2$ & 0.5 & $4.6 \mathrm{E}-2$ \\
\hline
\end{tabular}

${ }^{24} \mathrm{HEU}$ is already slightly radioactive (half-life of U-235 (dominant isotope) is $7.0 \mathrm{e} 8 \mathrm{yrs}$ ). The quantity listed corresponds to the maximum quantity used for the proposed action of $100 \mathrm{~g}$. Fission products result from a single target (maximum of $1.2 \mathrm{~g}$ ) subject to a 45-MJ fusion yield (4.6E16 fissions) and include residual fission products from previous yield shots $(60 @ 20 \mathrm{MJ})$. The fission product inventories are peak post-shot inventories.

25 Th-232 is already slightly radioactive (half-life of $1.4 \mathrm{e} 10 \mathrm{yrs}$ ). The quantity listed corresponds to the maximum quantity used for the proposed action of $450 \mathrm{~g}$. Fission products result from a single target (maximum of $7.9 \mathrm{~g}$ ) subject to a 45-MJ fusion yield (5.3E16 fissions) and include residual fission products from previous yield shots $(60 @ 20 \mathrm{MJ})$.The fission product inventories are peak post-shot inventories. 


\begin{tabular}{cccc}
$\mathrm{I}-132 \mathrm{~m}$ & $2.3 \mathrm{E}-3$ & 0.5 & $1.2 \mathrm{E}-3$ \\
$\mathrm{I}-133$ & $4.6 \mathrm{E}-1$ & 0.5 & $2.3 \mathrm{E}-1$ \\
$\mathrm{I}-133 \mathrm{~m}$ & $1.3 \mathrm{E} 1$ & 0.5 & 6.5 \\
$\mathrm{I}-134$ & 6.2 & 0.5 & 3.1 \\
$\mathrm{I}-134 \mathrm{~m}$ & 4.3 & 0.5 & 2.2 \\
$\mathrm{I}-135$ & 2.0 & 0.5 & 1.0 \\
$\mathrm{I}-136$ & $2.5 \mathrm{E} 2$ & 0.5 & $1.3 \mathrm{E} 2$ \\
$\mathrm{Te}-134$ & $1.8 \mathrm{E} 1$ & $1 \mathrm{E}-3$ & $1.8 \mathrm{E}-2$ \\
$\mathrm{Xe}-133$ & $9.0 \mathrm{E}-2$ & 1.0 & $9.0 \mathrm{E}-2$ \\
$\mathrm{Xe}-133 \mathrm{~m}$ & $3.7 \mathrm{E}-3$ & 1.0 & $3.7 \mathrm{E}-3$ \\
$\mathrm{Xe}-134 \mathrm{~m}$ & $2.2 \mathrm{E} 1$ & 1.0 & $2.2 \mathrm{E} 1$ \\
$\mathrm{Xe}-135$ & $6.2 \mathrm{E}-1$ & 1.0 & $6.2 \mathrm{E}-1$ \\
$\mathrm{Xe}-135 \mathrm{~m}$ & $2.8 \mathrm{E}-1$ & 1.0 & $2.8 \mathrm{E}-1$ \\
$\mathrm{Xe}-137$ & $1.8 \mathrm{E} 2$ & 1.0 & $1.8 \mathrm{E} 2$ \\
$\mathrm{Xe}-138$ & $6.2 \mathrm{E} 1$ & 1.0 & $6.2 \mathrm{E} 2$ \\
\hline
\end{tabular}

Tracers: Iodine is

bounding and

representative

I-124

I-125

$6.2 \mathrm{E}-2$

0.5

3.1E-2

$6.4 \mathrm{E}-2$

0.5

3.2E-2

I-126

$1.5 \mathrm{E}-1$

0.5

$7.5 \mathrm{E}-2$

Inner Container,

Weapons Grade

Plutonium (non-yield)

Pu-238

Pu-239

$3 \mathrm{~g}$

$1.0 \mathrm{E}-2$

$1 \mathrm{E}-3$

$1.0 \mathrm{E}-5$

$1.8 \mathrm{E}-1$

$1 \mathrm{E}-3$

$1.8 \mathrm{E}-4$

Pu-240

4.0E-2

$1 \mathrm{E}-3$

4.0E-5

$\mathrm{Pu}-241$

9.1E-1

1E-3

9.1E-4

Pu-242

$2.4 \mathrm{E}-6$

1E-3

$2.4 \mathrm{E}-9$

Am-241

$1.6 \mathrm{E}-3$

1E-3

$1.6 \mathrm{E}-6$

Inner Container,

Weapons Grade

Plutonium (with yield $^{26}$ )

Pu-238

Pu-239

Pu-240

Pu-241

$\mathrm{Pu}-242$

\section{$1 \mathrm{~g}$}

3.4E-3

$1 \mathrm{E}-3$

3.4E-6

$5.8 \mathrm{E}-2$

$1 \mathrm{E}-3$

$5.8 \mathrm{E}-5$

$1.3 \mathrm{E}-2$

1E-3

1.3E-5

3.0E-1

$1 \mathrm{E}-3$

3.0E-4

$7.9 \mathrm{E}-7$

1E-3

7.9E-10

26 The assumed composition of weapons grade material is $0.02 \% \mathrm{Pu}-238,93.85 \% \mathrm{Pu}-239,5.8 \% \mathrm{Pu}-240,0.3 \% \mathrm{Pu}-241$, $0.015 \% \mathrm{Am}-241$, and $0.02 \% \mathrm{Pu}-242$. Other isotopic mixes can be used as long as their impacts are within the bounds described here. The fission products result from a single target (maximum of $1 \mathrm{~g}$ ) subject to a 45-MJ fusion yield (3.2E16 fissions). Since only a single shot would occur within a containment vessel, only the fission products resulting from this single shot are included. The fission product inventories are peak post-shot inventories. 


Am-241
$\mathrm{Kr}-83 \mathrm{~m}$
$\mathrm{Kr}-85$
$\mathrm{Kr}-85 \mathrm{~m}$
$\mathrm{Kr}-87$
$\mathrm{Kr}-88$
$\mathrm{Nb}-98$
$\mathrm{I}-131$
$\mathrm{I}-132$
$\mathrm{I}-132 \mathrm{~m}$
$\mathrm{I}-133$
$\mathrm{I}-133 \mathrm{~m}$
$\mathrm{I}-134$
$\mathrm{I}-134 \mathrm{~m}$
$\mathrm{I}-135$
$\mathrm{I}-136$
$\mathrm{Te}-134$
Xe-133
Xe-133m
Xe-134m
Xe-135
Xe-135m
Xe-137
Xe-138

Inner Chamber Particulate

\begin{tabular}{cccc} 
Al-28 & $2.1 \mathrm{E}-1$ & $1 \mathrm{E}-3$ & $2.1 \mathrm{E}-4$ \\
$\mathrm{Si}-31$ & $8.1 \mathrm{E}-5$ & $1 \mathrm{E}-3$ & $8.1 \mathrm{E}-8$ \\
$\mathrm{P}-30$ & $4.5 \mathrm{E}-4$ & $1 \mathrm{E}-3$ & $4.5 \mathrm{E}-7$ \\
$\mathrm{~V}-49$ & $1.3 \mathrm{E}-6$ & $1 \mathrm{E}-3$ & $1.3 \mathrm{E}-9$ \\
$\mathrm{Cr}-49$ & $2.0 \mathrm{E}-4$ & $1 \mathrm{E}-3$ & $2.0 \mathrm{E}-7$ \\
$\mathrm{Cr}-51$ & $1.3 \mathrm{E}-4$ & $1 \mathrm{E}-3$ & $1.3 \mathrm{E}-7$ \\
$\mathrm{Mn}-52 \mathrm{~m}$ & $1 \mathrm{E}-3$ & $1.5 \mathrm{E}-8$ \\
$\mathrm{Mn}-54$ & $1.5 \mathrm{E}-5$ & $1 \mathrm{E}-3$ & $8.7 \mathrm{E}-9$ \\
$\mathrm{Mn}-56$ & $8.7 \mathrm{E}-6$ & $1 \mathrm{E}-3$ & $5.8 \mathrm{E}-5$ \\
$\mathrm{Fe}-55$ & $5.8 \mathrm{E}-2$ & $1 \mathrm{E}-3$ & $2.0 \mathrm{E}-8$ \\
$\mathrm{Co}-57$ & $2.0 \mathrm{E}-5$ & $1 \mathrm{E}-3$ & $1.5 \mathrm{E}-8$ \\
$\mathrm{Co}-58$ & $1.5 \mathrm{E}-5$ & $1 \mathrm{E}-3$ & $3.5 \mathrm{E}-8$ \\
$\mathrm{Co}-58 \mathrm{~m}$ & $3.5 \mathrm{E}-5$ & $1 \mathrm{E}-3$ & $5.1 \mathrm{E}-6$ \\
$\mathrm{Co}-60 \mathrm{~m}$ & $5.1 \mathrm{E}-3$ & $1 \mathrm{E}-3$ & $3.2 \mathrm{E}-5$ \\
$\mathrm{Co}-61$ & $3.2 \mathrm{E}-2$ & $1 \mathrm{E}-3$ & $2.2 \mathrm{E}-7$ \\
$\mathrm{Co}-62 \mathrm{~m}$ & $2.2 \mathrm{E}-4$ & $1 \mathrm{E}-3$ & $4.8 \mathrm{E}-7$ \\
$\mathrm{Ni}-57$ & $4.8 \mathrm{E}-4$ & $1 \mathrm{E}-3$ & $1.3 \mathrm{E}-7$ \\
$\mathrm{Ni}-65$ & $1.3 \mathrm{E}-4$ & $1 \mathrm{E}-3$ & $1.6 \mathrm{E}-8$ \\
$\mathrm{Nb}-96$ & $1.6 \mathrm{E}-5$ & $1 \mathrm{E}-3$ & $3.9 \mathrm{E}-9$ \\
\hline
\end{tabular}

5.2E-7

5.2E-4

$1 \mathrm{E}-3$

1.1E-1

3.0E-6

$2.6 \mathrm{E}-1$

1.6

9.6E-1

1.2

$1.9 \mathrm{E}-2$

8.0E-2

$9.0 \mathrm{E}-2$

3.2E-1

$1.7 \mathrm{E}+2$

4.2

$2.1 \mathrm{E}+1$

1.0

$6.5 \mathrm{E}+1$

$1.5 \mathrm{E}-2$

8.3E-2

$4.8 \mathrm{E}-3$

$1.7 \mathrm{E}+3$

$7.6 \mathrm{E}-1$

6.0

$1.7 \mathrm{E}+2$

$4.6 \mathrm{E}+1$

$4.6 \mathrm{E}+1$

1.0

1.0

2.1E-4

8.1E-8

$4.5 \mathrm{E}-7$

1.3E-9

2.0E-7

8.7E-9

$5.8 \mathrm{E}-5$

2.0E-8

5.1E-6

3.2E-5

2.2E-7

$1.6 \mathrm{E}-8$ 


\begin{tabular}{cccc}
$\mathrm{Nb}-97$ & $2.8 \mathrm{E}-5$ & $1 \mathrm{E}-3$ & $2.8 \mathrm{E}-8$ \\
$\mathrm{Nb}-97 \mathrm{~m}$ & $5.5 \mathrm{E}-4$ & $1 \mathrm{E}-3$ & $5.5 \mathrm{E}-7$ \\
$\mathrm{Nb}-98$ & $1.6 \mathrm{E}-2$ & $1 \mathrm{E}-3$ & $1.6 \mathrm{E}-5$ \\
$\mathrm{Mo}-93 \mathrm{~m}$ & $1.3 \mathrm{E}-6$ & $1 \mathrm{E}-3$ & $1.3 \mathrm{E}-9$ \\
$\mathrm{Mo}-99$ & $5.5 \mathrm{E}-5$ & $1 \mathrm{E}-3$ & $5.5 \mathrm{E}-8$ \\
$\mathrm{Tc}-99 \mathrm{~m}$ & $2.2 \mathrm{E}-5$ & $1 \mathrm{E}-3$ & $2.2 \mathrm{E}-8$ \\
\hline
\end{tabular}

Other experiments can be conducted within the envelope defined by the bounding release, but additional materials that would exceed the bounding release cannot be simultaneously present in the facility.

\subsubsection{Hazardous Material Release}

No new accident scenarios will be created as a result of the proposed action. However, the source term for the particulate release scenario will change. This is reviewed below. Several accident scenarios could result in the release of material in the particulate form. They are a waste drum fire, a target chamber vacuum window failure, and a beyond-design-basis earthquake.

The beyond-design basis earthquake is identical to the one described in the radiological release section. This scenario will be used as a bounding case to estimate the amount of material in particulate form released to the environment. The waste drum scenario and vacuum window failure scenario are bounded by the earthquake scenario because the associated release fractions are equal to or less than that for the earthquake.

\section{Source Terms}

An airborne release fraction of $10^{-3} \mathrm{can}$ be applied to the material in particulate form listed in Table 20. This gives the quantity of material that would become airborne, as summarized in Table 25 . No mitigation is assumed.

Table 25. Proposed Action Hazardous Materials Accident Source Term Due to Release of Particulate Inventories.

\begin{tabular}{|c|c|}
\hline Material & Quantity Released (g) \\
\hline $\mathrm{Be}$ & $2.0 \mathrm{e}-2$ \\
\hline $\mathrm{U}$ & $1.0 \mathrm{e}-1$ \\
\hline Th & $4.5 e-1$ \\
\hline $\mathrm{LiH}$ & $1.3 e-1$ \\
\hline
\end{tabular}

\section{Consequences}

Consequences should be assessed at $350 \mathrm{~m}$ from the facility (site boundary). 


\subsection{Decommissioning Operations}

The decontamination and decommissioning plan for the LTAB prepares the facility for controlled use by another DOE-sponsored program. Two issues dominate the complexity or ease with which structures in the facility will be decommissioned at the end of life: the extent of tritium contamination and the contact dose rate due to induced long-lived activation products. Tritium contamination will primarily be located in enclosures, such as gloveboxes, and in the target chamber and associated equipment. There may be some contamination of the target bay or decontamination area, resulting from small releases during routine change-outs of the collection system or as a result of any accidental releases. Activation products will exist in the structures in the target bay, such as the target chamber, space frame, and concrete. These may contribute to a small dose received by decommissioning workers. Some residual long-lived activation may be found in decontamination gloveboxes and in the decontamination area as a result of activated material that was transferred to these locations.

Several design principles that will minimize the $D \& D$ burden at end-of-life have been incorporated into the NIF design. These either minimize the total amount of contamination that could accumulate over the facility lifetime or make it easier to dismantle components at end-of-life. Design principles include:

- Design of components to simplify cut-up, dismantlement, removal, and packaging of contaminated equipment from the facility (e.g., dismantlement and removal of gloveboxes, air filtration equipment, large tanks, vessels, equipment, and ductwork).

- Minimization of items such as service piping, conduits, and ductwork in these areas, which should be arranged to facilitate decontamination.

- Design in ease of access, such as removable inspection covers, to allow for effective inspection and decontamination.

- Minimization of curves and turns in piping and ductwork to minimize the accumulation of radioactive or other hazardous materials in relatively inaccessible areas.

- Caulking or sealing and smooth-finishing racks, crevices, and joints to prevent contaminated material from accumulating in inaccessible areas.

- Use of modular, separable confinement barriers for radioactive and other hazardous materials to prevent or minimize the spread of contamination throughout the facility and to minimize contamination of fixed portions of the structure.

- Use of modular radiation shielding in lieu of, or in addition to, monolithic shielding walls. 
- Location of exhaust filtration components of the ventilation systems at or near individual enclosures to minimize ductwork surface contamination by tritium.

- Use of ventilation control (creation of confinement zones) to minimize the spread of contamination.

- Use of surface coatings to minimize tritium sorption.

- Use of low-activation materials.

\subsection{Decommissioning Worker Doses}

Materials have been carefully selected to minimize activation of the structural components of the LTAB. The target chamber and associated supporting structures are constructed of aluminum alloy. Aluminum is considered a low-activation material, producing primarily short-lived activity $\left({ }^{24} \mathrm{Na}, 15-\mathrm{h}\right.$ half-life). Some activation of the steel rebar in the concrete walls is longer lived. Low levels of activation can also be achieved by the use of borated concrete ("shotcrete") shielding around the target chamber. These features result in minimal end-of-life activity, minimizing the impact on decontamination and decommissioning (D\&D) activities.

The special equipment will be removed from the facility and disposed of as LLW, if appropriate. Some unique and/or valuable components will be packaged and stored for potential reuse. Other material with sufficiently low residual activity will be disposed of as regular industrial waste. During the course of these D\&D activities, workers will be exposed to residual radioactivity and contamination and will incur a dose. Facility features that are retained, such as the concrete floors and walls, and the fire protection system, have residual dose rates that are sufficiently low that the legacy of "long-term" restricted access may be avoided.

\subsection{Decommissioning Waste Estimates}

Any waste generated in conjunction with decommissioning activities will be safely disposed of. Chemical wastes arising during D\&D will include the capacitors (containing castor oil) and the mercury in the PAM ignition switches (see Table 26). These will be either recycled (mercury) or disposed of as hazardous waste (capacitors/oil) in an acceptable landfill. Residual minor contamination may be found in the capacitor bays (e.g., as a result of spills of oil during operation or during the equipment removal activity at end-of-life). Use of cleaning chemicals should minimize residual contamination.

LLW will also be generated during decommissioning, mainly from target area components. This will be disposed of at the Nevada Test Site. Estimated waste quantities are provided in Table 27. Airborne contamination created during the D\&D activities will be contained by use of tenting operations and HEPA filtration. 
Table 26. Estimated Quantities of Waste from Laser Decommissioning.

\begin{tabular}{lccc}
\hline \multicolumn{1}{c}{ Item } & Volume & Mass \\
& $\left(\mathrm{m}^{3}\right)$ & $(\mathbf{t})$ \\
\hline 192 PAM ignitron switches, $0.018 \mathrm{~L}$ each & 0.003 & 0.047 \\
4800 Capacitors - low hazard waste; castor oil on dielectric paper, $45 \mathrm{~kg}, 0.047$ & 226 & 216 \\
$\mathrm{~m}^{3}$ each [Recycling potential exists] & 226 & 216 \\
Total & 226 \\
\hline
\end{tabular}

Table 27. National Ignition Facility Target Area Low-Level Radioactive Waste Quantities from Decommissioning.

\begin{tabular}{lll}
\hline \multicolumn{1}{c}{ Item } & Volume $(@ 100 \%)$ & Weight (tonne) \\
\hline Final optics assemblies (hardware) & 43.0 & 116 \\
Target chamber & 23.6 & 63.8 \\
Target chamber cup & 2.21 & 5.98 \\
First wall and beam dumps & 16.1 & 11.5 \\
Gunite shielding & 100 & 244 \\
Vacuum systems & 2.02 & 8.42 \\
Plenum & 0.63 & 1.70 \\
Target positioner & 1.33 & 9.23 \\
Transport cryostat & 0.20 & 0.41 \\
Catwalks & 33 & 260 \\
Beam tubes & 8.6 & 23.3 \\
Diagnostic manipulators & 5.7 & 15.8 \\
Diagnostics & 0.67 & 0.90 \\
Cable trays and cables & 3.34 & 18.4 \\
Utilities & 14.2 & 87.5 \\
Fire Protection System & 0.496 & 3.9 \\
Subtotal for Target Area (items listed & 255 & 871 \\
above) & & \\
Tritium Processing System & 8.15 & 16.1 \\
\hline
\end{tabular}




\section{References}

CRC (1996), D.R. Lide and H.P.R. Fredrikse, Editors, CRC Handbook of Physics and Chemistry, CRC Press $76^{\text {th }}$ Edition, 1996.

Cummings D.(1991), Pulsed Power Ignitron Switches, Lawrence Livermore National Laboratory, UCRL-ID-108148, 1991.

DOE (2000), Memo for E. Beckner from D. Crandall, "Proposal to use certain materials in the National Ignition Facility (NIF): plutonium, other fissile materials, fissionnable materials, and lithium hydride," November 21, 2002.

DOE (1997), "Hazard Categorization and Accident Analysis Techniques for Compliance with DOE Order 5480.23," Nuclear Safety Analysis Reports, DOE-STD-1027, Rev. 1, September 1997.

DOE (1996), "NIF Project Specific Analysis," Programmatic Environmental Impact Statement for Stockpile Stewardship and Management, Appendix A, DOE-EIS-0236, September 1996.

Kimura C. and R. Glaser (1996), Estimate of Aircraft Crash Hit Frequencies onto Facilities at the Lawrence Livermore National Laboratory (LLNL) Site 200, UCRL-ID-127761, Rev. 0, July 1997.

Latkowski (1998), NIF Auxiliary Shielding Plan, Lawrence Livermore National Laboratyr, NIF-0013424, August 1998.

Latkowski, J. and M. Singh (1997), Measurement and Retrofit Plan for NIF Prompt Doses, Lawrence Livermore National Laboratory, NIF-0003376, September 1997.

LLNL (1998), National Ignition Facility Pollution Prevention and Waste Minimization Plan, Lawrence Livermore National Laboratory, UCRL-AR-131194.

LLNL (1996), National Ignition Facility Preliminary Safety Analysis Report, Lawrence Livermore National Laboratory, UCRL-ID-123759, September 1996.

NCRP (1977), National Council on Radiation Protection and Measurement, "Radiation Protection Design Guidelines for 0.1 - $100 \mathrm{MeV}$ Particle Accelerator Facilities, " NCRP Report No. 51, March 1977.

Ng, D. (1995), memo to M. Tobin and V. Karpenko, "Crack Study of the Target Area Building," LLNL Internal Document, SM95-043, March 1995.

Randerson, D. (1984), Editor, "Deposition and Resuspension" by A. Sehmel, in Atmospheric Sciences and Power Production,_U.S. Department of Energy, Washington DC, DOE/TIC-27601, 1984. 
Sporkin, S. (1998), United States District Judge, Memorandum Opinion and Order, United States District Court for the District of Columbia, Natural Resources Defense Council et al. Vs Federico Pena et al., Civil Action No. 97-0936 (SS), August 1998. 